Open Access

\title{
Supporting decision-making processes on blended learning in higher education: literature and good practices review
}

Álvaro Hernán Galvis

\author{
Correspondence: a.galvis73@ \\ uniandes.edu.co \\ University of Los Andes, Bogotá, \\ Colombia
}

\begin{abstract}
This article seeks to support decision-making processes in higher education institutions interested in using blended learning (from now on blearning) as a complement to other learning ecologies. It explores factors that could influence an institution's decision to implement blearning and addresses questions that should be answered in this regard. It aims to serve as a framework to strategic and tactical decisions around bLearning as a complement to other learning modalities. Questions aimed at supporting the construction of multidimensional bLearning environments that transform educational practices are raised around themes requiring critical analysis to materialize the bLearning implementation strategy: educational, operational and business models. This work concludes with an analysis of how to achieve the institutional transformation process, including how to articulate the bLearning modality with existing pedagogical approaches such that bLearning innovations become institutionalized and sustainable.
\end{abstract}

Keywords: Blended learning, Hybrid learning, Higher education, Strategic thinking, bLearning, bLearning educational model, bLearning operational model, bLearning business model

\section{Teaching and learning modalities in higher education institutions}

One of the most common tensions in higher education institutions (HEIs) is related to deciding which teaching methods and learning environments should be used to ensure quality and expand coverage (Green, 1994; Brookes \& Becket, 2007; Lee \& Im, 2014). Each of the existing modalities (face-to-face, virtual, and blended) have their advocates, though often arguments for or against a given methodology are often based on the what is in fashion at the moment.

\section{Face-to-face learning and technology-enhanced learning}

Traditionally, HEIs used the face-to-face modality, or traditional classroom instruction where teachers and students interact in person. This approach includes: close relationships between teacher and students, well-organized spaces in which necessary resources for teaching and learning are available, a campus with qualified staff. Technology enhanced learning environments can improve the educational offer and guarantee quality in higher education, yet in a context of increasing local and international competition (Kirkwood \& Price, 2014; Mykhnenko, 2016; Liu \& Chen, 2017).

(c) The Author(s). 2018 Open Access This article is distributed under the terms of the Creative Commons Attribution 4.0 International License (http://creativecommons.org/licenses/by/4.0/), which permits unrestricted use, distribution, and reproduction in any medium, provided you give appropriate credit to the original author(s) and the source, provide a link to the Creative Commons license, and indicate if changes were made. 
Technology becomes important when institutions face expansion. This situation presents challenges including tensions between coverage (reaching dispersed populations) and quality (offering excellent education services) (Green, 1994). Active pedagogies supported by digital technologies are often involved in innovations in the face-to-face modality because these can enrich face-to-face interaction; this is known as technologyenhanced education (Kirkwood \& Price, 2014). Despite this type of enhancement, technology-enhanced education still cannot achieve large-scale coverage due to infrastructure and staffing cost factors. It is impossible to distribute human talent beyond campus, this being the most valuable resource for meeting quality requirements. In many countries, certifications of institutions and programs teaching face-to-face have a welldefined framework of principles and procedures, thus making it possible to establish which HEI meets accepted quality standards (Brookes \& Becket, 2007).

\section{Distance education and virtual learning environments}

Distance higher education is another important modality used to increase coverage since it ensures that quality requirements are not inferior to those of the equivalent face-to-face education. Early distance education models were focused on content. Printed or audiovisual materials were made available to students who had sporadic interactions with tutors and counselors in centralized learning centers distributed in the regions targeted. In this modality, pedagogical and technological factors designed for this purpose are at the center of innovations (Galvis, 1982). The digital technologies allow for the creation and operation of a virtual (online) campus which promotes synchronous and asynchronous interaction with the available resources between all sides of the educational process (Galvis \& Pedraza, 2013). This provides the opportunity for learners to receive support, which is predominately virtual, in learning centers. It is worth noting that quality in this modality is also regulated by standards and procedures provided by accreditation entities, allowing for characterization and differentiation of what is offered in this modality and between the organizations (Tanweer \& Qadri, 2016). Meta-evaluations on the use of this modality (Means, Toyama, Murphy, Bakia, \& Jones, 2010) have helped to overcome resistance or skepticism about its use in HEIs. These evaluations state that HEIs do not only seek to expand coverage, but to improve educational quality; online education can make learning more flexible, and thus more effective.

\section{BLearning modality and multidimensional hybrid learning environments}

Rahman, Hussein, and Aluwi (2015, p. 769) mention that the literature reveals several definitions of bLearning, and the general consensus on bLearning characterization often unites the traditional face-to-face learning system and the electronic learning (eLearning) system, as proposed by (Graham, 2006). A report for the Online Learning Consortium-OLC (before, Sloan Consortium) defines "blended courses and programs, as having between 30 percent and 79 percent of the course content delivered online. Faceto-face instruction includes those courses in which zero to 29 percent of the content is delivered online; this category includes both traditional and web facilitated courses. The remaining alternative, online courses, are defined as having at least 80 percent of the course content delivered online" (Allen, Seaman, \& Garret, 2007, p. 5). A more 
recent report published by the same Consortium mentions that "as eLearning has evolved into a global change agent in higher education, it has become more diverse in its form and applications. This increased diversity has complicated our ability to share research findings and best practices, because we lack a shared set of definitions to distinguish among the many variations on eLearning that have arisen" (Mayadas, Miller, \& Sener, 2015). As a consecuence, a revised version of categories and definitions of courses and programs was proposed and shared by OLC, as summarized in Appendix 1. It is interesting to notice that this proposal refines Graham (2006) and helps differentiating seven types of courses and four types of programs, depending on how the course activity, or the program, mixes face-to-face and online activities (space for learning) as well as synchronous and asynchronuous activities (time for learning) when digital technologies are in use. Another interesting consideration is that "blended" and "hybrid" are considered synonyms, which is true, as long as there are mixes of spaces and times for learning in both cases. But it is conceptually short, as long as learning should be the focus of the different learning ecologies, and not only the blends of space and time for the student-teacher-interaction in doing learning activities.

In this regard, Singh (2003), cited by Rahman et al. (2015, p. 769) says that "in order for a learning approach to occur as blended learning the two characteristic must be combined so that it complements each other and promotes learning and applicationlearned behavior". Osorio Gómez and Duart (2012, p. 260-261) define "learning environment as a set of conditions in place for understanding learning activities", and explain that "when referring to blended learning, the term 'blended' expresses the aspect of combining face-to-face instruction with ICT-mediated instruction. However, different combinations of instructional approaches or instructional methods are possible, one of which is hybrid learning."

Above considerations lead to highlight the pedagogical dimension of blending and gives this flavor to the hybrid approach to learning, in which the intention to promote learning, while getting the best from the combination of opposite but complementary modalities [face-to-face, online], matters. "The hybrid concept constitutes a potential continuum in the teaching-learning process as it can be seen as the expansion and continuity of space-time (face-to-face and distance, synchronous and asynchronous) in the learning environment. The challenge of the hybrid approach therefore is to achieve integration between face-to-face and eLearning actions in the delivery of learning activities, in such a way that each adds value to the other in a continuous process that leads to learning objective attainment." (Osorio Gómez \& Duart, 2012, p. 261).

The continuum notion as related with learning environments is very important to understand. As explained by Osorio Gómez (2011, p. 73-76) hybrid learning activities are not limited to what happens in the classroom (face-to-face and virtual classrooms) but also include activities in autonomous learning spaces; this expands space and time for learning and breaks the discrete approach to the design of instruction. "The metaphor of the continuum refers to the notion of connecting and integrating, as opposed to the fragmentation, division and discretization of the learning environment. When hybrid environments are constructivist learning environments, the interaction StudentStudent and Student-Instructor should enhance the individual and collaborative construction of knowledge in a continuous process at both the theoretical and methodological levels. (Osorio Gómez, 2009, p. 245)”. 
It is evident from the above conceptual revision that there are several dimensions to be considered to design blended learning environments. Table 1 gathers two schemas to create multi-dimensional blends in learning ecologies. Besides the first dimension considered by (Singh, 2003) and (Galvis, 2017a), which deal with interrelated concepts, the rest four dimensions are mutually complementary. Each of these lenses help to understand multiple possibilities of blending pedagogical and technological resources.

The multi-dimensionality of the blend is a framework that agrees with Rossett and Frasee's perspective on bLearning (Rossett \& Frasee, 2006, p. 2). They argue that blended learning environments "integrate seemingly opposite approaches, such as formal and informal learning, face-to-face and online experiences, self-directed and directed instruction, as well as digital references and personal connections, to achieve individual and institutional [learning] goals." The relevant characteristics to understanding this multi-dimensional framework are that bLearning:

$\triangleright$ Recognizes that education occurs in formal (e.g., classroom), non-formal (e.g., work, communities of practice) and informal learning environments (e.g., media, websites), building on the strengths of each learning environment.

$\triangleright$ Highlights the fact that both human facilitators and digital technologies can play a key role in education; a selective combination of these means can be the basis for rich, sustainable and expandable learning experiences.

$\triangleright$ Recognizes alternative and complementary paths for learning, promoted by individuals but also by collective efforts. A well-conceived combination of learning paths can lead to curriculum plans that allow for education, personal growth, and productive life to align.

$>$ Accepts that interaction with content stored in repositories can complement interaction with facilitators and co-workers or peers, by physical or digital means; a combination of exchanges that considers the nature of what is learned and the desired level of expertise, which can lead to the creation of rich, flexible, effective and sustainable learning experiences.

In addition to finding appropriate multidimensional blends for a given educational context, another great challenge of the bLearning modality is to make the most of faceto-face and virtual modalities when they are used to provide blended learning ecologies

Table 1 Two lenses to look at dimensions of the blend

\begin{tabular}{ll}
\hline Dimensions of the blend (Singh, 2003) & Dimensions of the blend (Galvis, 2017a) \\
\hline $\begin{array}{l}\text { Offline (face-to-face) and online (virtual) learning } \\
\text { environments }\end{array}$ & $\begin{array}{l}\text { Spaces (face-to-face, online, autonomous) and } \\
\text { time (synchronous, asynchronous) for student- } \\
\text { teacher-content interaction }\end{array}$ \\
$\begin{array}{ll}\text { Self-paced (learned controlled) and live, collaborative } \\
\text { learning (among many learners) }\end{array}$ & $\begin{array}{l}\text { Pedagogy (conventional, inverted) and locus of } \\
\text { control (teacher, students, group) }\end{array}$ \\
$\begin{array}{ll}\text { Structured (formal) and unstructured (informal) learning } \\
\text { Media to attain knowledge (expository, active, } \\
\text { interactive media) }\end{array}$ \\
$\begin{array}{l}\text { Custom content (adaptive, flexible) and off-the-shelf } \\
\text { content (generic) }\end{array}$ \\
$\begin{array}{l}\text { Learning (before a new job-task), } \\
\text { practice (using job-tasks or simulation models), } \\
\text { and performance support (Just-in-time coaching) }\end{array}$
\end{tabular}


(Pavla, Hana, \& Jan, 2015). After more than a decade of experimenting with and reflecting on the use of this modality at the University of los Andes Center for Innovation in Technology and Education (Conecta-TE), our experience has shown that transformative bLearning programs - those where bLearning is used to foster educational change aligned with the plan for institutional development-require attention to a combination of organizational, educational and operational factors of success (Galvis \& Osorio, 2017).

Studies have shown that perceived value of bLearning has the most significant contribution on students' satisfaction on bLearning: "when students perceive their learning as relevant, interesting, and enjoyable, the value of learning satisfaction increases" (Rahman et al., 2015, p. 773). These authors also established that this is followed by easy of use, a technology-based design-factor; the third unique contribution is learning climate, since a positive learning climate encourages the exchange of ideas, new information and knowledge. This depends on trust and cooperation between students. Last, but not least, is student-instructor interaction, which includes instructor delivering information, support the students as well as provide feedback on students' works.

\section{Focus and conceptual framework}

This article aims to outline factors that support institutional decision-making processes around challenges in these three complementary dimensions mentioned. The paper seeks to answer the question:

How can sound pedagogical, operational, and organizational conditions for bLearning to thrive in HEIs be created?

Key subordinate questions will also be addressed, and include:

- How can strategic institutional thinking about bLearning programs and courses in HEIs be developed?

- How can tactical decision-making processes behind the implementation of bLearning strategies proposed by a given educational organization be supported?

To tackle these questions, expert focus group sessions were conducted. Participants included expert bLearning stakeholders at the University of los Andes, most of whom have created and taught bLearning programs and courses for more than a decade. The goal was to determine big ideas, i.e., fundamental concepts, (Mitchell, Keast, Panizzon, \& Mitchell, 2017) needed to be addressed to conduct this study. Based on reflection and a collective discussion, we created a mind map that expresses big ideas to be developed in order to solve questions of interest. This map was later refined upon interaction with other bLearning experts from HEIs that are leaders in the use of technology-based education, as is shown in Fig. 1.

With this mind map as a reference, we carried out a systematic literature review around strategic and tactic issues to support decision making processes concerning bLearning in higher education. Selected studies were included because of their relevance, endurance of results, conceptual clarity as well as because of pertinence of cases in consideration. This led to update a benchmark study on good practices and lessons learned in the use of bLearning/eLearning at HEI in Europe, North and South America, that the author had 


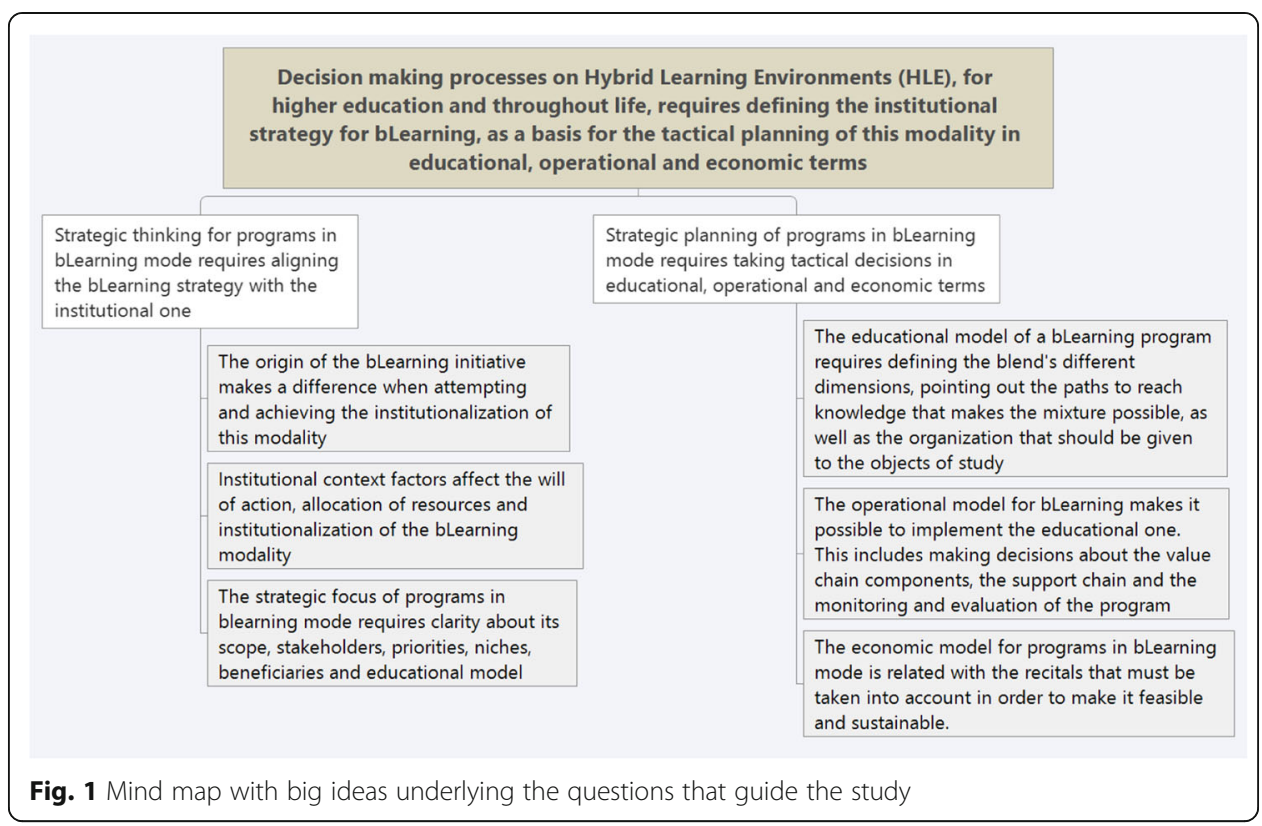

conducted (Galvis \& Pedraza, 2013). Six case studies were revised in collaboration with key informants from Universitat Oberta de Catalunya [Spain], Instituto Tecnológico de Monterrey [México], Babson College [Massachusetts], Pontificia Universidad Católica del Perú [Perú], FLACSO-PERT [Argentina], and Universidad de los Andes [Colombia] (Galvis, 2017b). Appendix 2 shares interview guides prepared with this purpose. This was done with the aim of understanding the evolution of each case in the 3 years after the original benchmark. Based on the findings, we collaboratively authored with the informants six case studies about bLearning/eLearning in higher education and are included in a book in print (Galvis, 2018, in press).

We also reviewed studies tracking innovation in education (Rogers, 1983) and analyzing change processes around technology-enhanced pedagogy in HEIs (Graham, Woodfield, \& Harrison, 2013; Porter, Graham, Spring, \& Welch, 2014; Porter \& Graham, 2016). It was clear that the institutionalization of innovations such as bLearning goes well beyond the application of best practices. Articulating the bLearning modality with the modus operandi of an organization requires negotiation and agreement between those who believe in current approach and those who believe that strengthening and/or expanding is worth considering.

Furthermore, this study builds on previous research related to the meaning of teaching in the digital age (Ginns \& Ellis, 2007; Bates, 2015; Brown, 2016), which is a broad domain which discusses enhanced learning, blended learning, and virtual learning.

\section{Strategic thinking about bLearning programs}

Strategy is not the consequence of planning; on the contrary, it is a starting point: "strategic planning, as it has usually been practiced, is in fact strategic programming, entailing the articulation and elaboration of strategies or visions that already exist ... In contrast, strategic thinking is related with synthesis, the generation of innovative ideas, new perspectives; it entails intuition and creativity" (Mintzberg, 1994, p. 107-108). Building on these concepts, we proposed the following set of guiding questions as a 
frame of reference to strategically plan a program or a course using the bLearning modality:



The following paragraphs present findings regarding guiding questions \#1, from literature review and above-mentioned case studies.

\section{Leadership and rationale for adoption and institutionalization of bLearning}

Initiatives in bLearning do not grow spontaneously. There are people, reasons or circumstances that lead actors to consider the desirability of offering a bLearning program in an educational organization. Examining the following perspectives can help to uncover this.

\section{The rationale behind offering a bLearning program/course}

The study by Galvis and Pedraza (2013) shows that it is worth understanding the origin of the intention to offer educational opportunities that were flexible in terms of space, time and modality. That said, there are different implications for these reasons depending on from whom and where they arise. The consequences vary if the forces leading the change are in the top management of an organization, in potential stakeholders, or in potential beneficiaries, as opposed to emerging collectively from learning communities interested in gaining access to flexible or alternative learning opportunities.

\section{Reasons leading to the use of blended learning environments}

In order to meet the needs that foster a bLearning initiative and reveal what cannot be accomplished with educational solutions in the existing modalities, it is important to establish why the intertwining of learning environments is considered. Case studies reviewed by Galvis (2017b) showed that, usually, the goal is to reach people who do not have access to a formal face-to-face education. These are often people who have no experience as learners in virtual environments but want to overcome space-time barriers to gain effective access to education opportunities throughout life. Likewise, the desire to maximize the use of the physical infrastructure, such as increasing classroom availability, could be a reason for using virtual spaces. Additionally, the quality of bLearning can match other modalities if the appropriate mixture of the following is provided: interactions types (face-to-face and distance); means (expository, active or interactive); 
control schemes over the learning process (teachers, students, groups of learners); and learning environments (work, home, educational institution, virtual classroom, face-toface classroom). Given this range of possibilities (Galvis, 2017a), it is important to understand why a diversity of combinations in the bLearning initiative occur.

\section{Institutionalizing the use of blended learning environments}

Within any educational institution, it is likely to find teachers and managers who are eager to explore innovative options, such as offering courses or programs in blended learning environments. Still, it is not common for those individual initiatives to become institutional ones. However, if the initiative has been institutionalized, it is important to understand how this has happened. Was the initiative the result of an internal drive to innovate (e.g., through benchmarking) that was piloted prior to its institutionalization (Burkei, 2014), or is the institution willing to make such transformations as part of its mission (this is known as the reengineering of educational processes)? (Penrod \& Dolence, 1992).

\section{Factors that influence the blearning initiative}

The context of a system includes everything that can affect it without being directly influenced by it; when a factor is influenced by the system, it ceases to be context and becomes an organic part of the system (Churchman, 1968). This definition is very useful to streamline what a bLearning initiative program or course and its context can be. In some cases, it can be an institution, a department, another program, or it can be all the above. For this paper, we consider the following possible contextual elements, even though in some cases they may no longer be of contextual nature, because they are all key to this endeavor: institutional strategy, board level commitment, social adjustment versus bLearning modality, level of maturity for bLearning adoption.

\section{Aligning the blended modality with the institutional strategy}

Each organization has its own strategy to succeed in achieving its mission and accomplishing its projected goals. In this regard, it is vital to be clear about the role that blended modality can play as a differentiating educational factor, as an element that adds value to the learning process, or as an element that ensures a sustainable, competitive advantage for the organization. These qualities seem to be at the core of what Ohmae (1990) calls wise competition. It is also essential to achieving an alignment between the business strategy of the educational organization and the blending strategy of the chosen program. Educational and computer technologies can become an organizational transformation factor (Henderson \& Venkatraman, 1994) insofar as they consider not only the instrumental components (what is included in that process' chain of support), but also the essential one (what is included in the value chain of the educational process).

\section{Board level commitment with the bLearning modality}

As obvious as it may seem, without an effective managerial commitment in a bLearning program context, it is impossible for this type of initiative to thrive. Studies 
on best practices in eLearning and bLearning programs (Galvis \& Pedraza, 2013) show that this type of commitment is a key factor in making the following possible:

$\triangleright$ Using the teacher's time as authors, course directors, facilitators, or evaluators as part of their academic load, or compensating them when their contribution to the program is not part of their teaching responsibilities;

$\triangleright$ Relying on sufficient and appropriate financial resources to design and implement the program, and then to implement, replicate or expand what has been designed. (A medium-term investment recovery can be expected);

$\triangleright$ Rethinking fundamental processes present in the chain of educational value and aligning technological, administrative, and financial support processes with these fundamentals according to the desired dimensions for the blend.

\section{Socio-technical adjustment towards bLearning}

Socio-technical studies analyzing Organization, Individual and Technology (OIT) relationships have shown that the period of time between the commitment to technology and its strategic use in an organization (from barely wanting to explore it until it is institutionalized) is affected by the individuals' differences in expectations, opinions, perceptions and attitudes (e.g. those of managers versus technicians) (Sáez Vacas, 1997). In this regard, it is very important to pay special attention to this transition through social adjustment processes that promote innovation awareness and appropriation. These move from a minor problem in the context to the mitigation of differences that significantly affect processes and products. As stated by Sáez Vacas (op. cit., p.47) "when we talk about social adjustment to technology, in fact, we are alluding to the subtle network of adoption curves of each involved individual or group, immersed in a very competitive territory of struggle for power and survival."

\section{Maturity stages of a blended modality program or course}

The maturity to do something relies on the capability to carry that thing out in a given context. In order to discover the characteristics of a mature bLearning program or course, it is relevant to build on the multiple dimensions of this concept (Galvis, 2017a) and to consider the possible related contextual factors (Solar, Sabattin, \& Parada, 2013). Figure 2 displays areas for improvement which are those with the lowest scores.

$>$ BLearning Normativity. According to Allen et al. (2007) the bLearning modality must offer between $30 \%$ and $79 \%$ of contents online, thus reducing face-to-face time. From this perspective, it is possible to consolidate the bLearning program according to worldwide standards for a blended modality program accreditation. This will depend on whether it is a national or international accreditation body and how these establish the guidelines and percentages for online content. Institutional level regulations could also exist, insofar reducing face-to-face interaction for the sake of virtual interaction is accepted.

$\triangleright$ Face-to-face distribution and media literacy. The distribution of educational opportunities (Mason \& Rennie, 2006), that is, the amount of opportunities on site and synchronous for the face-to-face component, and the amount of opportunities that can be accessed from anywhere and asynchronously for the virtual component, can also be evidence of maturity for bLearning. This considers the possibility of conducting 


\section{Blended modality maturity ( 0 to $5,0=$ Null, $5=$ Max)}

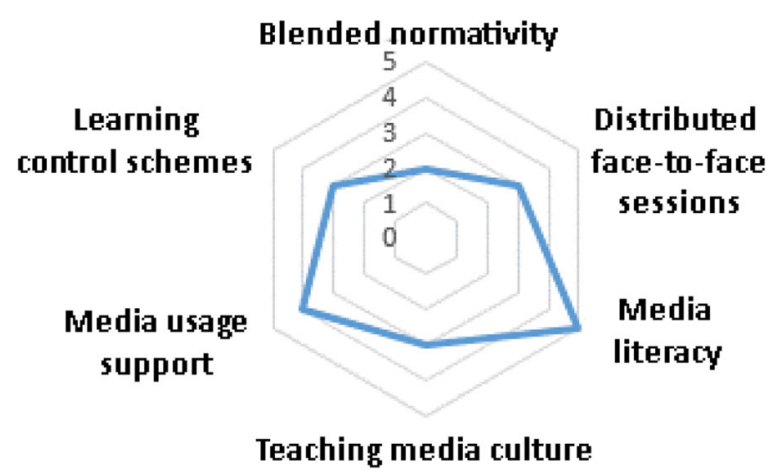

Fig. 2 Hypothetical case of multidimensional maturity for blended modality

face-to-face sessions for groups that are geographically dispersed (known as face-toface distribution), as well the teaching staff and the participants making use of different sorts of media to access content. Depending on the program's geographical scope, it may be necessary to have one or more locations for the face-to-face component, either directly operated by the institution offering the course or program, or operated in association with local institutions. Media literacy for the virtual component cannot be taken for granted. Depending on the program participants, those who have already taught or learned with ICT support have probably acquired necessary skills, but otherwise, it is necessary to promote and teach media literacy in the face-to-face session in which the program begins.

$>$ Media culture in teachers. Depending on the intended goal and the medium's specificity, it is possible to combine active, interactive, and expository media (Forté \& Wentland, 1998) to support diverse learning styles (visual, auditory and kinesthetic) (Bersin, 2004), and to promote the achievement of different types of learning outcomes (information transmission, cognitive abilities, motor skills, attitudes). The maturity of this dimension has two complementary edges: the instructional and the institutional one. When the educational culture in media usage is very conventional, using predominantly expository means for teaching, the support for the hybrid modality is elementary. Nevertheless, when the educational culture in media usage is different and also aims at a diversity of objectives and ways to reach knowledge, the level of maturity is higher. $>$ Media usage support. Institutionally speaking, the level of maturity is related with the support given to teachers and students for the use of different types of media (Solar et al., 2013). If maturity is limited to addressing access and functionality problems of each media, there is little maturity from this perspective. If it includes strategies to support an adequate use of media through which knowledge is attained, there is a high level of maturity.

$>$ Learning control schemes: Pedagogically speaking, maturity to support learning in mixed environments is determined by the control scheme's mindset. It may be centered on the teacher, who transmits knowledge, on the learners, who build knowledge, or on groups, who share and reconstruct knowledge (Forté \& Wentland, 1998). When the program design seeks a balance of emphasis according to the type of results and 
processes it leads, higher pedagogical maturity is required in the environment designers and in teachers; when the educational paradigm allows everyone to make use of their own teaching style without a pedagogical model guiding the process, less maturity is required.

\section{Focusing learning programs on blended learning environments}

bLearning entails a series of basic definitions that create synergy between the components of the program offered. The teleological ${ }^{1}$ definition of a bLearning program demands a clear educational model, its scope, needs and market niches as well as its stakeholders and beneficiaries (Galvis, 2017a).

\section{Desired scope for a bLearning program}

Within the context of an educational institution, the bLearning modality can be used at different levels or complementarily: learning units, courses, study programs, or group of these. Deciding on a particular scope leads to important structural and procedural implications. Once the scope is established, the institution must decide what characterizes its blending choice (its 'touch' or its 'trademark') and how to ensure its quality (Galvis, 2017a). If only a few learning units will implement bLearning, the accompaniment for their design and development can be tailored following the principles of the educational model and without making major adjustments to the value chain and support processes for faceto-face or online courses. However, if bLearning is implemented within whole programs, alignment of processes in the value chain is mandatory (Galvis, 2017b).

\section{BLearning program interest groups / stakeholders}

By identifying internal and external groups of interest, stakeholders, as well as categorizing them according to the interest in and power to influence the conceptualization, materialization, offer, follow-up and evaluation of a bLearning program, it is possible to determine the dissemination strategy among the stakeholders. This stakeholder analysis which uses problem analysis and a logic of creating opportunities for all participants can be useful to outline partnerships, seek sponsorship or recognition from influential groups in the domain of interest, as well as to create formal or informal functional relationships (Svendsen \& Laberge, 2007).

\section{Needs that should be met with offers in bLearning environments}

Educational needs are often seen as discrepancies between the desired state and the present state in terms of providing an educational service (Jannetti, 2012). To identify needs, a variety of sources are often used, depending on the type of needs to be considered (Suffolk County Community College, 2004). In the case of formal higher education programs, priority is usually given by normative needs, meaning those derived from the desire to comply with a rule, to meet requirements or standards. In contrast with current practices, this is the origin of many structural reforms in higher education programs. However, to provide a better service to the target population, initiatives that tend to be more flexible, usually responding to perceived needs of the potential beneficiaries or service providers, should be implemented. These could add much value to the current ones. Comparative needs are also often considered. These imply contrasting services or peer programs to indicate which discrepancies should be addressed or should be intensified if widening the gap is a differentiating factor. 


\section{Desired market niche(s) for a bLearning initiative}

After reviewing these perspectives to shape the program's focus, it is worth exploring two possible ways of approaching potential market niches: (1) If the program has a distributed geographical scope, it is very important to ensure that the allocated face-toface component can be offered with the same properties and quality as those of the home environment, that is, those of the institution where the program was created. For this purpose, it is possible to consider strategic alliances with peer educational institutions in the regions of interest as they can be useful to conduct a shared marketing and logistical management, as well as academic management that builds on the partners' strengths (Galvis, McIntyre, \& Hsi, 2006). (2) If the program targets include an economic sector, or serve a world-class international organization, it is quite possible that the most important blend of learning environments is composed of organizations from this sector, or of segments of such organizations. In this case, it is possible to combine learning in a working environment with learning in an educational environment, taking advantage of the opportunities offered by the partner's knowledge management, communities of practice in their organizations, as well as the possibilities of syndication and subscription to specialized digital resources in this sector (Rosenberg, 2006).

\section{Characteristics of the program's potential beneficiaries}

Programs in bLearning are open in some dimensions, such as the time and space to study the online component. This does not mean that they are suitable for anyone interested in the subject, even if the learner meets the conditions for admission and has the financial, technological and logistical resources to study. Learners' possible intrinsic and extrinsic motivators, potential family and organizational facilitators and inhibitors for adults learning in blended environments can help or hinder their success. Therefore, when designing these types of programs, it is important to gather sufficient knowledge about the target population. Also, it is key to publicize what it means to take part in the program, perhaps through video clips or face-to-face sessions which explain what taking part in these types of sessions entails and what it means to join a blended learning community. This information helps stakeholders to make informed decisions (Galvis, 2017b).

\section{Outlining the educational model in a bLearning program}

The educational model is one of the dimensions of blending that should be considered when designing a program (Galvis \& Pedraza, 2013). The educational model can be left open, which means that the creators of virtual learning environments impose their own teaching model within the program's curriculum framework, under the premise that everyone comfortably shares a teaching style and that it is possible to align this with media support. It is also possible to have an institutional educational model, such as the one proposed by the UOC (2009) to its learning community (see Fig. 3) where the common denominator for any course and program is its tendency towards a thirdgeneration educational model. This would not imply a schism for the coexistence of environments of other generations.

The importance of having a clear institutional educational model (or the lack of one) lies in that everyone involved - students, teachers and directors- knows what to expect and what they are responsible for. Likewise, it is convenient to set indicators of achievement and ways of evaluating these indicators. 




An interesting educational model to review within the eLearning context is the one developed for VHS (Virtual High School) in the Concord Consortium, or CC (Tinker, Haavind, Galvis, Rose, McIntyre, et al., 2002). CC's eLearning models became a paradigm that illuminated the transition from distance education by correspondence to the digital format, to eLearning, while materializing conjectural, collaborative and experiential learning with ICT support.

\section{Tactical decision-making for bLearning initiatives}

Tactic, in one of its meanings, is understood as a plan, procedure for promoting a desired end or result. ${ }^{2}$ In this case, it is a matter of implementing strategic thinking. To achieve this, this section shares guiding questions and related principles for building or revising educational, operational and business models that can help to materialize bLearning designs.

\section{Educational model for bLearning environments}

An educational model is related with each set of elements that make it possible for beneficiaries of a bLearning program to participate in it, to learn and become certified, if applicable (Galvis \& Pedraza, 2013). Its components are the program's backbone and include the: (1) characterization of the blended learning environments, modes of interaction, and applicable resources; (2) examination of options to reach knowledge; (3) decisions about knowledge organization. These elements do not follow a pre-established order and there is much interaction between them, so adjustments in one component can modify another. The following guiding questions/instructions result from the literature review (Lai, Lam, \& Lim, 2016) and/or the analysis of good practices in eLearning / bLearning (Galvis, 2017b). They are outlined here to help decision-makers in shaping or adjusting the educational model for bLearning initiatives: 
Set of Questions \#2. Blending environments, modes of interaction, resources and learning times

- Learning environments: In this course, or program, which learning environments are the best to take advantage of? Are the physical and virtual classrooms usually included in the bLearning offer sufficient? Is there interest in fostering experiential learning from what is done at work, and/or from what happens in the physical environment close to the learner, and/or in field trips?

- Interaction modes and resources: In each of the chosen learning environments, different modes of interaction can be used to attain knowledge. Interactions can take place through the use of various types of media: interactive in which users engage with each other; active, which are organically engaging; expository, which transmit messages. Considering what one wants to achieve and the chosen learning environments, which learning resources are relevant to the environments and modes of interaction applicable to your case?

- Learning times and environments: Build a timeline with the maximum duration of a course, defining each of the planned face-to-face / virtual cycles. Define the schedule for the combination of virtual / face-to-face environments. Keep in mind that you want to take full advantage of each environment's potential. Be sure that the times and activities for each learning cycle are enough to achieve the proposed objectives.

Set of Questions \#3. Pathways to reach knowledge

- Desired/convenient pedagogy to be implemented: If the course or program is aimed at having characteristic trademark, define whether conventional or active pedagogy is to be promoted in the learning units; otherwise, give the author freedom to define how students should be encouraged to learn. ${ }^{3}$

- Type of classroom setting to be operationalized: The blended modality can be used with conventional or active pedagogy, but also with conventional classroom practices (students go to the classroom to learn and then consolidate and generalize) or with flipped classroom approach (students learn before attending faceto-face sessions and then consolidate and generalize). Define if the educational model will impose some type of classroom type, or if it is the educators' choice to decide how to conduct their course.

Set of Questions \#4. Content structuring and development

- Define how to organize the course's content. Use fine approximations such as: weekly distribution; using the book's core chapters; modular approach around linked to fundamental concepts, also called big ideas. In any case, it is expected that the learning cycle (motivation, acquisition, reinforcement, and generalization) will be achieved in a sequence that best fits the chosen pedagogy.

The subsequent sections present what the literature review and follow up from the aforementioned cases (Galvis, 2017b) show regarding the guiding questions and/or instructions above.

\section{Mixing learning environments, modes of interaction, and resources}

The definition of bLearning proposed by Rossett and Frasee (2006), and the multidimensional aspects of it highlighted both by Singh (2003) and Galvis (2017a), can be better illustrated when different blends are considered, as shown in Table 2 (updated from Galvis et al., 2006, p. 14). This example does not aim to be inclusive or current in terms of technologies, it is just an exemplification of the potential of considering multidimensional blends for this modality.

\section{Time distribution and academic workload in blended learning environments}

An emerging issue with the mixing of modalities to promote learning in bLearning environments concerns time. The academic workload is a consideration that must be taken into account. Activities must be organized considering time distribution so that synchronous tasks (same day and time, not necessarily at the same place when using communication technologies) and asynchronous ones play the best possible role in the educational model and that it is appropriate for the class-interaction time. Factors related to workload and time management are commonly related to the number of credits.

A reasonable mixture of face-to-face / virtual interaction, when participants are geographically dispersed is to meet in the physical classroom every 4 weeks, usually on weekends. This combination has been successfully used in many University of los Andes 
Table 2 Resources to promote learning using blended learning environments in formal and non-formal settings Source: (Galvis et al., 2006, p. 14)

\begin{tabular}{|c|c|c|c|c|}
\hline \multirow[t]{3}{*}{ Type of media } & \multicolumn{2}{|l|}{$\begin{array}{l}\text { Formal Learning } \\
\text { Setting (Classroom) }\end{array}$} & \multicolumn{2}{|l|}{$\begin{array}{l}\text { Informal Learning } \\
\text { Setting (Workplace) }\end{array}$} \\
\hline & $\begin{array}{l}\text { Physical } \\
\text { classroom }\end{array}$ & Virtual classroom & Virtual Office & Physical office \\
\hline & $\begin{array}{l}\text { Human-based, } \\
\text { offline }\end{array}$ & ICT-based, online & ICT-based, online & $\begin{array}{l}\text { Human-based, } \\
\text { offline }\end{array}$ \\
\hline $\begin{array}{l}\text { Interactive media } \\
\text { (allow learning } \\
\text { through interaction } \\
\text { and collaboration } \\
\text { between people) }\end{array}$ & $\begin{array}{l}\text { Discussion } \\
\text { groups } \\
\text { Case discussion } \\
\text { Problem-based } \\
\text { learning } \\
\text { Expert consultation } \\
\text { Role playing }\end{array}$ & $\begin{array}{l}\text { Online forums } \\
\text { / discussion groups } \\
\text { Interactive case } \\
\text { discussion } \\
\text { Interactive problem- } \\
\text { based learning } \\
\text { Online expert } \\
\text { consultation } \\
\text { Collaborative games } \\
\text { / simulations }\end{array}$ & $\begin{array}{l}\text { Distributed learning } \\
\text { communities (LC) } \\
\text {-Task-based LC } \\
\text {-Practice-based LC } \\
\text {-Knowledge-based } \\
\text { LC } \\
\text { Online consultation } \\
\text {-With colleagues } \\
\text {-With experts } \\
\text { Collaborative tools } \\
\text {-Productivity } \\
\text { - Knowledge } \\
\text { management }\end{array}$ & $\begin{array}{l}\text { Local learning } \\
\text { communities } \\
\text {-Task-based LC } \\
\text {-Practice-based } \\
\text { LC } \\
\text {-Knowledge- } \\
\text { based LC } \\
\text { Consultation } \\
\text {-With colleagues } \\
\text {-With experts } \\
\text { Mentoring } \\
\text { Peer coaching } \\
\text { Retreats }\end{array}$ \\
\hline $\begin{array}{l}\text { Active media (allow } \\
\text { learning by inquisitive } \\
\text { exploration of learning } \\
\text { objects or tools) }\end{array}$ & $\begin{array}{l}\text { Exercises } \\
\text { Field trips } \\
\text { Games } \\
\text { Simulations } \\
\text { Functional models } \\
\text { Sensors } \\
\text { Working tools } \\
\text { Physical search }\end{array}$ & $\begin{array}{l}\text { Drills + feedback/ } \\
\text { reinforcement } \\
\text { Web quests } \\
\text { Stand-alone e-games } \\
\text { Stand-alone } \\
\text { e-simulations } \\
\text { Digital models } \\
\text { + data capturing } \\
\text { Digital sensors } \\
\text { + data capturing } \\
\text { Productivity tools } \\
\text { Digital search / } \\
\text { Internet / Portals/ }\end{array}$ & $\begin{array}{l}\text { Knowledge Management } \\
\text {-Individual syndication } \\
\text { / blogs } \\
\text {-Group / syndication } \\
\text { / blogs } \\
\text { - Organizational / } \\
\text { data bases } \\
\text { Just-in-time active } \\
\text { learning tools } \\
\text { Personal support tools } \\
\text {-Help system, wizards } \\
\text { Productivity tools, } \\
\text { Working tools } \\
\text { Search / Internet } \\
\text { / Portals/ }\end{array}$ & $\begin{array}{l}\text { Knowledge } \\
\text { Management } \\
\text { Individual } \\
\text { Handbooks } \\
\text { and manuals } \\
\text { Physical search }\end{array}$ \\
\hline $\begin{array}{l}\text { Expositive media } \\
\text { (allow learning } \\
\text { by transmission } \\
\text { of knowledge) }\end{array}$ & $\begin{array}{l}\text { Demonstration } \\
\text { Lecture } \\
\text { Video conference } \\
\text { Audio conference } \\
\text { Digital video } \\
\text { Digital audio } \\
\text { Books, magazines }\end{array}$ & $\begin{array}{l}\text { Digital-demo } \\
\text { e-Tutorial } \\
\text { Video conference } \\
\text { Audio conference } \\
\text { Digital video / } \\
\text { video casting } \\
\text { Digital audio / } \\
\text { pod casting } \\
\text { Portals, eLibraries, } \\
\text { Group websites } \\
\text { Shared personal } \\
\text { portfolios }\end{array}$ & $\begin{array}{l}\text { RSS Syndication } \\
\text { from } \\
\text {-Search agents } \\
\text {-Watch lists } \\
\text {-Productivity tools } \\
\text {-Social networks } \\
\text {-Peer produced } \\
\text { content } \\
\text {-Blogs } \\
\text {-Pod casts } \\
\text {-Video casts } \\
\text {-Personal portfolios }\end{array}$ & $\begin{array}{l}\text { Subscription to } \\
\text {-Magazines } \\
\text { - Reference } \\
\text { services } \\
\text { Non formal } \\
\text { learning events } \\
\text { - Invited lecturers } \\
\text { - Brown bag } \\
\text { lunches } \\
\text {-Seminars } \\
\text {-Conferences } \\
\text {-Video } \\
\text { conferences } \\
\text {-Audio } \\
\text { conferences }\end{array}$ \\
\hline
\end{tabular}

$\mathrm{ICT}=$ Information and Communication Technologies, LC = Learning Communities

bLearning graduate study programs since it allows participants from different regions of the country to work and study at where they live and to Uniandes' campus to participate in one or more blended course sessions, depending on how many course credits per semester they are taking (Galvis \& Osorio, 2017). Table 3 illustrates this algorithm:

When students are not geographically dispersed, it is possible to consider variations in time distribution of hours per week through the semester, quarter or bimester, depending on credits, or ECTS, ${ }^{4}$ per blended course and on the number of weeks per academic term. For instance, Table 4 shows how a 2-credit course per semester could be offered in blended learning modality in three different ways, depending on the class 
Table 3 Time mix of learning modalities in a bLearning graduate program (Source: Uniandes) Week 0: Face-to-face meeting to create community, develop a sense of belonging, appropriate the use of ICT, and program introduction. Four academic cycles, each:

Weeks 1, 2, 3 per academic cycle I $(I=1 . .4)$ : Self-paced online individual or small group academic work, to appropriate / explore / produce knowledge. Academic charge of $4 \mathrm{~h}$ per week per credit.

Week 4 per academic cycle I ( I = 1..4): Face-to-face session, small / large group work, to deepen / debate / exchange knowledge with professor and classmates. One hour per credit

session length, as well as on physical classroom availability. This is a typical undergraduate course case, where students are on campus and it is convenient to reduce to physical class sessions by $50 \%$.

Table 5 shows how a 3-credit course per semester could be offered in bLearning modality in six different ways, depending on the class session length and on physical classroom availability. This is a typical undergraduate course case, where students are on campus and it is convenient to reduce to $50 \%$ or to $66 \%$ of physical class sessions.

\section{Ways to achieve knowledge favoring the program's defined blend}

The chosen blend must not be detached from the pedagogy used to implement the program (Galvis \& Pedraza, 2013). Considering the contributions of learning psychology, it is possible to consider two main approaches to acquire knowledge depending on who is at the core of the process. If the teacher is delivering the knowledge, behaviorist ideas can be very instrumental. These help to organize the activities created by the teacher to encourage learners to appropriate the relevant mental models. If the student, or learning groups, must actively acquire knowledge, it may be very instrumental to use ideas from cognitive psychology in which the subject, acting on objects of study, leads them to the construction their own mental models about what was studied. Case-based learning, problem-based learning, and projectbased learning methodologies use the principles of the latter and very good applications of these practices exist, particularly in fields such as medicine, business administration and law.

These ideas might lead to empowering two opposites, but complementary, bLearning models: conventional classroom and flipped classroom (Galvis, 2017b). In both cases the learning cycle is the same: motivation, appropriation, refinement and generalization of the concepts learned. In the first model, the appropriation of knowledge occurs through the teacher's act of sharing knowledge in the classroom where students appropriate it, then refine and generalize in the virtual environment. In the second model, the students are exposed to content in the virtual environment before face-to-face interaction. Then they use their findings to dialogue with the teacher and with other colearners about challenges, cases and problems that can be subject to collaborative work.

Table 4 Time mix of learning modalities in a 2-credit bLearning course (Source: Author)

\begin{tabular}{llllll}
\hline 2-credit course & Face-to-face & Week 1 & & Week 16 & \\
\hline $1 \mathrm{H} /$ session & $50 \%$ & $1 \mathrm{PC}$ & $1 \mathrm{VC}$ & $1 \mathrm{PC}$ & $1 \mathrm{VC}$ \\
$1 \mathrm{H} /$ session & $50 \%$ & $1 \mathrm{PC}$ & $1 \mathrm{PC}$ & $1 \mathrm{VC}$ & IVC \\
$2 \mathrm{H} /$ session & $50 \%$ & $2 \mathrm{PC}$ & & $2 \mathrm{VC}$ & \\
\hline
\end{tabular}

$H$ hours of classroom interaction, $P C$ physical classroom interaction, $V C$ virtual classroom interaction 1 credit $=3$ to $4 \mathrm{~h}$ of study / week along 16 weeks 
Table 5 Time mix of learning modalities in a 3-credis bLearning course (Source: Author)

\begin{tabular}{llllllll}
\hline 3-credit course & Face-to-face & Week 1 & \multicolumn{5}{c}{ Week 16 } \\
\hline $1 \mathrm{H} /$ session & $66 \%$ & $1 \mathrm{PC}$ & $1 \mathrm{PC}$ & $1 \mathrm{VC}$ & $1 \mathrm{PC}$ & $1 \mathrm{PC}$ & $1 \mathrm{VC}$ \\
$1 \mathrm{H} /$ session & $66 \%$ & $1 \mathrm{PC}$ & $1 \mathrm{VC}$ & $1 \mathrm{PC}$ & $1 \mathrm{PC}$ & $1 \mathrm{VC}$ & $1 \mathrm{PC}$ \\
$1 \mathrm{H} /$ session & $66 \%$ & $1 \mathrm{VC}$ & $1 \mathrm{PC}$ & $1 \mathrm{PC}$ & $1 \mathrm{VC}$ & $1 \mathrm{PC}$ & $1 \mathrm{PC}$ \\
$1.5 \mathrm{H} /$ session & $50 \%$ & $1.5 \mathrm{PC}$ & & $1.5 \mathrm{VC}$ & $1.5 \mathrm{PC}$ & & $1.5 \mathrm{VC}$ \\
$1.5 \mathrm{H} /$ session & $50 \%$ & $1.5 \mathrm{VC}$ & & $1.5 \mathrm{PC}$ & $1.5 \mathrm{VC}$ & & $1.5 \mathrm{PC}$ \\
$3 \mathrm{H} /$ session & $50 \%$ & & $3 \mathrm{PC}$ & & & $3 \mathrm{VC}$ &
\end{tabular}

$H$ hours of classroom interaction, $P C$ physical classroom interaction, VC virtual classroom interaction

1 credit $=3$ to $4 \mathrm{~h}$ of study / week along 16 weeks

Self-management of the learning process that precedes the face-to-face session in the flipped classroom model does not necessarily imply active pedagogy (i.e., studentcentered or group-centered), since it makes sense to convey fundamental concepts through technology (e.g., using video clips per each concept). It is possible to take advantage of face-to-face interaction to build knowledge on solid foundations and around problematic situations that require input from other participants and facilitators. ${ }^{5}$

\section{Content structure and development}

At first glance, content structuring does not seem too related with the educational model applied to a bLearning program. If a bLearning course seeks to promote certain types of skills, abilities, and proficiencies within a disciplinary domain and is offered with a blend of classroom and online activities, then the time frame of this blend should set the tone to organize content. For example, in the time sequence of 4 weeks per cycle illustrated in Table 3 it is "natural" for contents to cycle through a four-week period and for each cycle to develop a learning unit in bLearning mode. This could eventually also include flipped pedagogy. However, the courses are not always structured in large thematic units. Topics can be divided in the manner proposed by the curriculum or textbook, for example, one learning unit per week; within this, one faceto-face session could be held and the rest conducted virtually.

Another way to approach content structuring in bLearning environments is around the discipline's big ideas, also called fundamental concepts (Erickson, 2007, p. 7). In this case the course creation team makes use of a three-dimensional instructional design consisting of: what to understand (each fundamental concept), what to know (facts), and what to do with it (skills). From this perspective, it is possible to overcome issues of two-dimensional instructional design (involving facts and skills) ensuring, from its very conception, the sustainable understanding of each big idea. This approach to teaching usually includes performance evaluations. Challenges situated in real contexts are used as learning strategies, and essential higher-level thinking questions are used to guide the inquiry, and solution to these questions are always authentic (Wiggins \& McTighe, 2001).

The idea just mentioned presents an interesting disjunction between the conceptual and operational elements because in the first approach (thematic), the organization and development of contents does not necessarily imply a methodology, although it must make use of the defined multidimensional blend. Meanwhile, the second approach (big ideas) is bound to an active pedagogy that revolves around inquiry and solution of 
authentic problems. Galvis and Pedraza (2012) present a methodology to redesign courses from the big ideas perspective.

\section{Operational model for teaching in a bLearning modality}

An operational teaching model refers to the set of elements that make it possible to implement the educational model. It includes decision-making processes related to the program and its courses, organizational structure to articulate processes, strategies to produce materials, student management throughout the course creation value chain, ICT management for the program, marketing and communication, management of tutorials and accompaniment, evaluation of effects and impact and follow-up with graduates.

The following guiding questions/instructions resulted from the literature review and/ or the analysis of good practices in eLearning / bLearning (Galvis, 2017b) and are provided to help decision-makers shape or adjusting the operational model for bLearning initiatives:

Set of Questions \#5. Define the normative framework for the chosen program or course.

- Official program registration. If it is a program, does the official registration or qualification already exist? What is the standard on the blearning modality to be used? If not, what do you have and what does it take to achieve it?

- Course curricular plan. When referring to courses, what defines the curricular plan in which students are immersed? What guidelines for course virtualization are being considered?

- Program management. Is there a curricular management committee for the program to be offered in mixed mode? Who are the committee members? What requires their approval?

Set of Questions \#6. Organize and articulate procedures of the value chain and support processes

- Program adscription. To which organizational unit does the program in blended modality belong? - Management of the value chain components. What elements of the value chain will be assumed by the organizational unit "owner" of the program or course? Which ones will be made in alliance with other organizational units? Which ones are going to be outsourced and to whom?

- Working teams. Which working teams will be involved in the development of processes along the value chain? How will these teams be coordinated? What experience do you have with multidisciplinary team management and what lessons have you learned?

- Knowledge management. How do you plan to do the knowledge management which is associated with the value chain? Will there be a shared repository to store information about the design, development, monitoring and evaluation of the complete program and each of its components? What are the guidelines for systematizing information in the repository?

- Resource management. What is planned for the resource management (financial, human, physical, technological, documental, authorship) of the components for the program or courses to be offered in blended learning modality? Is there an integrated management system with other programs or courses of this modality? Who is responsible for each task and how do you monitor the flow of management processes? - Dissemination. What is planned for marketing, communications and social media for the components of the program or courses to be offered in bLearning modality? Is there an integrated management system with other programs, or courses, of this modality? Who is responsible for each task and how do you monitor the flow of dissemination processes?

Set of Questions \#7. Formulate or refine strategies to produce materials for the program or course

- Production of materials. What is decided about the production of materials for the program or course to be offered in bLearning modality? Will materials be created within the organization? Will this production use resources created by others?

- Production times and costs. What are the budget ceilings and deadlines for the production, acquisition or adequacy of materials?

- Strategy for original production. If production is going to be handled in-house, will this be in a handcrafted way, according to each author's criteria? or will it be done on a professional level and be handled by specialized groups?

- Adjoining production strategy. If this process is going to use open access materials created by others, what repositories of Virtual Learning Objects (VLOs) and Virtual Learning In vironments (VLEs) have been consulted, or do you plan to consult? Who will select and curates resources? If it is necessary to adapt or locate them, who will do it and when?

- Materials purchase strategy. If commercially-owned materials will be bought or adapted, who are the suppliers of these resources? What are the terms of use? 
- Quality assurance guidelines. Which guidelines will be used to ensure the quality of materials and learning environments for education? They may be internal to the organization, may be international standards. What is planned in this regard?

- Copyright guidelines. What are the organization's copyright guidelines? How will ownership of online or physical works that arise from the program or course be certified?

Set of Questions \#8. Define how to monitor and manage students along the value chain

- Knowledge of the beneficiaries. Have you characterized potential students? What findings condition, or influence, the preparation and implementation of the program or course? If this information is not available, when, how and who will get it?

- Introduction to the modality and to the program or course. How do you plan to introduce the bLearning modality and to the program or course? Who is involved, when and for what reason? What means should be used to ensure the friendliness and quality of this process?

- Counseling / coaching services. Will there be these kinds of services for students in bLearning modality? What organizational unit will provide them? What will be the virtual / face-to-face nature of these services? What will the counselors' functions be? How integrated are the counseling information systems expected to be with the student management system of the program or course?

- Academic tutoring. Will these services be available in the courses of the modality? What kind of background, training or certification must be demonstrated by those who provide this service? Are these tutors organized by course, by group of courses, or by program? What follow-up is done, or should be done, to the performance of the tutors and who is responsible or should be responsible for this?

- Achievement evaluation and certification. What should be considered for the evaluation of learning and

certification of achievements at course level? Do any institutional guidelines exist? or can each course creator(s) define this according to their own criteria? What policies need to be met in relation to academic achievement information at certain times in the academic calendar?

- Feedback information. How is the student's opinion recognized throughout the program? Who gives feedback to those responsible for the various elements of the value or support chain based on findings about student opinion?

The following sections present the literature review and lessons learned from good practices (Galvis, 2017b) regarding the above set of guiding questions/instructions.

\section{Policy framework for programs and courses in blended learning environments}

It is to be expected that every program and course have their leaders, managers, owners, but this does not mean everyone can do as they please. For instance, formal programs offered by HEI in Colombia must be framed within the qualification standards outlined by the National Ministry of Education (MINEDUCACION, 2003). Some other types of programs are framed by the authorizations granted by the academic authorities of the respective HEI. Courses, in turn, are part of the approved curriculum and the guidelines prepared by the National Ministry of Education (MINEDUCACION, 2012) for the design, production and implementation of virtual courses. Since this does not generate a normative context for the courses and programs in the bLearning modality, it is considered a good practice to have a curricular administration bLearning committee where the respective innovation is to be implemented. This committee focuses on the updating and adjustment of these types of programs and courses and operates as a mechanism for consultation and authorization if need be.

\section{Articulation of processes in chains of support and value}

Processes required to carry out a program that uses blended learning environments and that is supported using information and communication technologies are shown in Fig. 4. The central arrow includes, in a sequential order, the processes of the value chain; that is, those that add value which the identification of the stakeholder's needs to the fulfilling of these (Porter, 1982). 
Management of resources (financial, human, physical, technological, documentary, authorship)

Marketing, communications, social networking

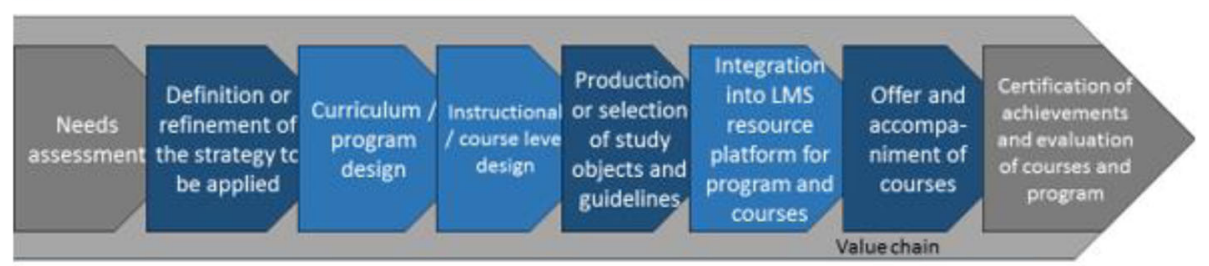

Knowledge management associated with the value chain

Fig. 4 Blended learning program and course value and support chain processes. Source: author

The substantive processes of a bLearning program, which are its fundamental components, belong to its "value chain", generate products and make possible educational services, such as:

$>$ Study of training needs: A document stating what policy guidelines and what normative, perceived or comparative needs are the basis of the desired program or course.

$\triangleright$ Educational strategy to apply: A document that makes explicit what makes this program or course unique, what differentiates it from similar initiatives and what is expected to make it attractive to the target population.

$>$ Program or course curricular design (macro level design): A document that establishes the characteristics of the program or course to be offered in bLearning modality. These traits should be in accordance with the applicable rules, whether they are international, national or institutional.

$>$ Instructional design (micro level design): Documents that specify each of the course units in the program to be offered. This design seeks to provide clarity about the purpose (needs), contents (topics and objectives), proficiency (evaluation system) and methods and resources for each course's learning units.

$>$ Learning objects and study guides: These are the resources that will make it possible to acquire the knowledge, including those that the student must interpret (learning objects) as well as those that give the student guidelines about how to carry this out this interpretation (study guides).

$>$ LMS Learning Management System: This is a digital system where it is possible to create virtual classrooms and repositories that allow the course participants to learn using the resources that have been organized by subject and articulated. Through this platform it is possible to use each of the tools chosen to support the process and leave evidence of learning.

$>$ Accompaniment: There is usually a course director in charge who focuses on and monitors course activities. Tutors, one per 20 to 25 students, provide support to academic processes. Counselors per cohort of students help to solve non-academic problems affecting the learner.

$>$ Certification of achievements and course and program evaluation. Each course has a learning evaluation system that allows instructors to collect evidence of achievements. 
Using these, the institution can certify the results of any given course or program. The evaluation of these academic services are embedded in the course and serve as a basis for making appropriate decisions to adjust the course or program.

In parallel with the substantive processes three groups of support procedures are presented:

$>$ Resource management: This ensures the availability of resources that intervene in the development of a bLearning program. Without neglecting the traditional administrative efforts of every organization (financial, human resources, physical infrastructure), it is crucial to ensure that the others (digital systems and technologies, libraries and collections, copyrights) are effective.

$>$ Marketing, communications and social media: These act as the face of the programs and manage the interaction with the outside world through audiovisual, social and interactive media.

$>$ Knowledge management (KM) associated with the value chain: This element is an internal process that provides the guidelines and supports for the organization of knowledge around the educational innovation. It is very important to articulate KM with the processes in the value chain because it plays a role in institutional learning in that it systematizes and disseminates knowledge generated by the various processes of the value chain.

From the organizational point of view, there are many decisions to make, to build an efficient and viable operating structure. Below are some considerations derived from best practices (Galvis, 2017b):

$>$ Functional specialization: Academic units related to the nature of each bLearning program ensure the pertinence of the content, timeliness and organization, management of the teaching-learning processes and evaluation of lessons, as well as monitoring the program and its components. Besides, the educational innovation requires that the value chain processes be completed and thus there is a need for an entity or organization that offers pedagogical, technological and evaluative accompaniment and direction to the development of these processes.

$>$ Finding a place for the educational innovation unit in the organizational structure: Depending on the desired level of outreach in the bLearning initiative, and of the desire of those seeking external connections around education innovation and related research, it is convenient for the education innovation unit to be part of the institutional staff. This can be as a unit of service (as is the case of computing services, libraries) or as part of the academic vice-rectory staff in which case the unit is seen as a business partner for each of the faculties or departments.

$>$ Execution of value chain processes: A golden rule for this is to self-execute the processes that give competitive advantage or are linked to one of the key success factors. Subcontracting specialized groups can be done under appropriate supervision. Those processes that other parties can competently complete at reasonable prices and times, without destabilizing the key factors of success can be contracted (e.g., creating dependency on a supplier). The manner in which the processes of the value chain are executed can determine personnel in the educational innovation unit. 
$>$ Work teams: Formal and informal higher education programs have a disciplinary or multi-disciplinary nature. Most of the processes in the value chain are methodological (pedagogical or evaluative) or technological (computer-based or audiovisual). Therefore, it is important to create work teams to carry out each process. Leadership of the bLearning program can be carried out by a coordination team, while each course requires its own production unit.

$>$ Internal coordination of processes and resources: For a bLearning program or course to be offered on time and with the expected quality, it is important to do detailed planning, programming and monitoring of each of the processes in the value chain.

This requires articulating times, resources and deliverables within each working team.

\section{Production strategies of bLearning program materials}

Organizationally and strategically, it is important to consider whether the production of online learning materials will be done internally or externally, artisanally or industrially, and with or without resources for free access. Whatever the case, production requires copyright acknowledgement in addition to license payments when resources are not open access.In some cases, the institution will want materials and learning environments to be a differentiating factor. Usually, this implies that the organization produce and release its own virtual learning objects (VLOs) with copyright protection. Servers that require users to have authorization for accessing resources and downloading copies are instrumental; such is the case with institutional Learning Management Systems (LMS) and Content Management Systems (CMS). In other cases, the institution may decide to give Open Access (OA) to the materials and virtual learning environments created for its courses, like those available in digital repositories such as MERLOT, ${ }^{6} \mathrm{OCW},{ }^{7}$ TEMOA $^{8}$ or XPLORA. ${ }^{9}$

The decision of whether to use OA materials makes a difference for designing, developing and maintaining a bLearning program. OA resources must be used as they are and with no obligation to update them or make them permanently availability. If the resource is also Open Source (OS), limitation of updating can be overcome because of the availability of the source code and the commitment to sharing improvements within the community of users. On the Creative Commons ${ }^{10}$ website, it is possible to find the existing types of licenses as well as the specific conditions for each of them.

If the unit decides to produce materials internally, authors can be guided on techniques for creating and editing digital audio or video, as well as on using resources that the institution has included in its support toolbox. It is also possible to use a media production group (internal or external to the institution) to help create and refine audio, videos, simulators, games, web pages or other required materials. In any case, the important thing is having well-founded, clear guidelines that help to design, develop, test and adjust the materials, as well as matching production to budgets and timelines.

The challenge with materials is also related with copyright, which must be respected. The unit must recognize the authorship of the sources and register the works that arise from educational innovation projects. There is a convenient guide about online and physical registration of materials in Colombia and the registration of photos and videos from mobile devices (MININTERIOR, 2016).

\section{Student management throughout the value chain}

The value chain begins and ends with the customers (Porter, 1982), in this case, the stakeholders who choose to participate in a proposed bLearning program, as displayed 
in Fig. 4. Analysis of good practices in eLearning / bLearning show that there is a tacit process within the value chain: student management (Galvis, 2017b). This process refers to the necessary tuning of the program characteristic towards participation opportunities for participation of the program beneficiaries. It also deals with the accompaniment that enables the student to move forward in their learning process in blended environments. The following are key considerations about student management:

$>$ It begins with the characterization of the target population including the recognition of their current learning environments, their stage of life. This provides a context in which to design programs and courses, produce materials and organize the virtual learning environments.

$>$ When materializing the program offer, student management is related both with orientating students to the modality and also to accompanying them through advising and feedback from the program's counselors and course tutors.

$>$ It is key that students develop a sense of community (Rovai, 2002) for their interaction in both virtual and face-to-face spaces.

$>$ It is also important to maintain continued supervision of their participation in individual and group activities, which can be done with learning analytics offered by the LMS, as well as with the use of alerts.

$>$ These follow-up systems are valuable for the facilitation of participatory processes, where accompaniment with indirect light by facilitators makes a difference in the processes of inquiry and participant interaction (Collison, Elbaum, Haavind, \& Tinker, 2002).

$>$ Likewise, proper and well-defined feedback on learning processes and products, either by peers or by facilitators, can truly enhance participation.

$>$ At the end of each course, and at the close of the program itself, student management includes the certification of student achievements.

$>$ Student management also implies considering what has been gathered in the grading system, as well as the learners' feedback about their experience through surveys and/or focus groups. This can improve future processes based on the customer's response.

\section{Business model for bLearning programs}

The business model for a program in bLearning modality includes aspects that must be considered to make it a viable and sustainable offer. Literature on costs and funding of educational programs in this modality is practically non-existent; the studies by Bart (2008) and Rumble (1999 and 2001) on eLearning modality are the most related resources available. Building on Rumble's (2001) proposals on pricing of online programs, we propose that the business models for bLearning programs should take two elements into account: 1) variables that can be controlled and that have an influence on costs; 2) cost factors associated with the development of materials, the courses offerings and program management.

The following guiding questions/instructions arise from literature review and/or the analysis of good practices in eLearning/bLearning (Galvis, 2017b), and are outlined to help decision-makers in shaping or adjusting the business model for bLearning initiatives: 
Set of Questions \#9. Calculate costs for the participant in a bLearning program or course

- Tuition fees. What is the program's tuition fee and what is included in this payment? Consider the cost of academic guidance and counseling, teaching and certification services; also learning digital resources, such as e-books, digital videos, exercise simulators and games. Consider digital services such as virtual libraries, laboratories equipped with computers, research kits, laptops, tablets or portable digital equipment and Internet connection.

- Costs to be paid by the student. What costs should the participant assume? Consider the digital technology required for each of the learning environments, the costs of attending face-to-face meetings (direct costs, such as travel and lodging expenses; opportunity costs, such as unpaid leave), and expenses derived from objects of study that are not included in the program's tuition fee.

- Financial challenges for enrollment. Consider the beneficiary's characteristics and the funding systems or scholarships available. Do they make it possible to expect effective demand, considering the costs of enrollment and personal costs for participating in the program? What challenges are expected in the program's offer to make it financially attractive to the target population?

Set of Questions \#10. Determine internal costs associated with program development

- Cost-changing factors. Considering the blend of media defined for the program, what are the major cost factors? What production or acquisition strategies are suitable to rationalize costs without risking differentiation?

- Models to produce different types of materials. Which production model should be used for the different types of materials and what are the associated times for each resource type? Consider the course syllabus, study guides, texts, exercises, simulators, games, video clips, audio clips, and websites. What type of materials should an author-editor model use and what are the associated costs? Which media should be produced by a multidisciplinary team and what costs does it entail? In case you have established metrics for each type of material, what do these metrics say about the time required to prepare each type of material? - Production: internal or outsourced? Considering the offering plan for the blended modality program or course, is the installed capacity sufficient to produce materials, or is it necessary to subcontract? If the latter is necessary, for which parts of the program or course? How efficient is the organization when handling outsourcing processes?

- Program's lifespan. To ensure the program's viability, what lifespan should it have? How many cohorts are needed to ensure the investment recovery? In case of open access throughout the year, how many students are needed to reach the break-even point?

Set of Questions \#11. Internal costs associated with the program offer

- Management costs. What is the institutional overhead on income for the program or course to be offered in blended modality? Is it possible to request that it not be applied as until the program reaches the break-even point? What has not been included in this surcharge that could be a potential expense for the program or course?

- Costs of technological services. What is the added cost of the program or course to be offered in blended modality from the perspective of platform and technological services, access to databases and digital library services? Are these costs included in the institutional overhead?

- Marketing costs. Using the marketing structure that is the most cost-effective for your organization, what are the marketing costs associated with each of the areas of the program or course that you want to offer in blearning modality? To what extent can these costs be shared with other programs using the same modality? - Flow of human and technological resources. Given the course offering plan and strategies for student management, what human and technological resources will be required to address student management throughout the program?

- Staff hiring policies. What is the policy for hiring course directors, tutors, counselors and what are its strengths and weaknesses? How can the teaching load of the academics (course directors, tutors) who take part in the course offer in bLearning mode be balanced? Is the background knowledge of graduates or retired teachers being exploited in any way? What estimates should be made regarding graduate assistants and professionals with less experience? What budget forecasts does this entail?

- Resources for management, monitoring and evaluation. What human and technological resources are needed for the management, monitoring and evaluation of the program or course to be offered? Is it desirable for the program or course to have its own management, monitoring and evaluation systems, or are these better done in conjunction with other programs in the same modality?

The following paragraphs present the literature review and lessons learned from best practices (Galvis, 2017b) regarding the above set of guiding questions/instructions.

\section{External costs of a program in bLearning modality}

External costs, which are passed on to the user or to the sponsor, can be a crucial factor to determine the program's viability because they can determine if stakeholders take an active part in the offer. A program's design encourages stakeholders to perceive 
the added benefit, but their decision to participate considers associated costs as well. Thus, the following considerations should be kept in mind:

$>$ It is key to pay attention to the costs of enrollment and of learning objects (materials and digital collections) when these are not included in tuition. Likewise, it is key to explore and share the possible options to cope with costs (scholarships, loans, personal funds), as these charges, and how to deal with them can be a decisive factor in attracting and retaining potential participants.

$>$ It is appropriate to estimate the participant's operating costs. These might include travel expenses and possible work permits to attend face-to-face sessions, availability of computer equipment, and communication systems to participate in virtual sessions or marginal costs for their use.

\section{Internal program costs in the creation phase}

When the convenience of offering a program has been established, it is very important to predict its financial viability. It could be that a niche has been identified where the blended modality offers competitive advantages and can make a difference. The following points summarize critical factors in internal costs from experience and the literature review:

$>$ Production of materials according to their type. Depending on what is most convenient type of media to use in a bLearning program, more or less specialization and effort are required for production. A study by Arizona Learning Systems (ALS, 1998, p. 13-14) quoted by Rumble (2001, p. 7) showed that the most cost-effective way to produce materials is to only produce the program including its study guides and assessments. If the program wishes to produce text, audiovisual, or interactive materials such as exercises, games, simulators or virtual reality applications, production costs can be significantly increased in a proportion from 1 up to 150 between the lowest and highest cost option. Audiovisual and interactive materials that make good use of the potential each media has require participation of multidisciplinary teams, which demand important investments. One way to reduce these costs, and eventually production times, is by doing adjoining production. This consists of selecting and adapting resources that match the requirements. These can be either open access (available in digital repositories of open resources), or copyrighted (available through an organization owner of the copyright).

$>$ Production costs and strategies to reduce them. As for the effort involved in the materials development, in addition to the ALS findings already mentioned (ALS, 1998), Rumble (2001, p.79) reviews a study by Sparkes (1984, p. 219) who states that an academic needs between 2 to $10 \mathrm{~h}$ to prepare a conference, 1 to $10 \mathrm{~h}$ to prepare a small group session, 3 to $10 \mathrm{~h}$ to prepare a video recording, 50 to $100 \mathrm{~h}$ to prepare a text, around $100 \mathrm{~h}$ to prepare a live TV session, $200 \mathrm{~h}$ to prepare a tutorial and about $300 \mathrm{~h}$ to prepare an interactive software, not counting the time of the technical staff supporting the process. Many faculty would agree that these figures are not far from current ones, being the expertise of the academic and the possibility of repurposing available resources what makes the difference. Rumble points out that one way of keeping production costs within an acceptable range is by using an author-editor 
model with advisors supporting the author, rather than having permanent staff in charge of producing materials. He also states (p. 80) that because the quality of materials is critical, to achieve cost-efficiency, it is better to seek savings in recurrent costs such as course promotion.

$>$ Technologies that will be used to support learning and management of a bLearning program. Having this kind of technology makes a difference and it is worth studying the best way to use it from the beginning of the program or course production. It is possible to pay the license fee for the use of LMS or CMS systems and have support for the operation, or to subcontract related services. The chosen option must ensure the best cost-benefit scenario. Security, completeness and interoperability of the information should be insured. Since these systems are often institutional and non-exclusive to bLearning programs, it is necessary to determine the bLearning marginal costs, unless the intention is to include them within the overhead costs, as can be the case with library costs and digital collections.

$>$ Program expected lifespan. Investment costs of materials are amortized over the program's lifespan, which must be established to estimate the feasibility and return of investment.

\section{Program internal costs in its execution phase}

To start a program, or course, in bLearning modality, clarity about the purpose of the offer and the educational resources available might not be the only requirements. It is also necessary to ensure viability at least in the medium term.

$>$ Program revenue overhead. The central management of educational institutions usually covers their expenses by adding an extra cost to tuition fees or services paid by clients and sponsors. Infrastructure is often included in these costs, which makes it possible to offer programs, such as classrooms, auditoriums, technologies, digital document collections, information and communication services, maintenance and security. If any of the central services required by the program or course in bLearning modality is not included in the overhead, it is necessary to include it in the budget. Creating programs in bLearning modality can be included within politics of institutional development, so it should be considered if the overhead can be applied only after reaching the financial break-even point.

$>$ Marketing of the program or course. The materialization of a blended learning modality offer depends on obtaining a sufficient demand so that the income is not inferior to the expenses. For this reason, it is very important to establish how many cohorts are needed to ensure the return of investment, as well as the way to reach the target population and potential sponsors. Marketing has a cost and takes time, so it is important to decide whether it should be done by an internal or external specialized department or if it is the program's responsibility. In any case, it is necessary to establish what the cost and time associated with this task for each program or course offer is.

$>$ Number of simultaneous beneficiaries in courses per program. Usually programs are organized by cohorts, and the size of these indicates the magnitude of learning support services (mentoring, course leadership) and management (counseling, face-to-face meeting logistics). These are important parameters for the respective costing. 
$>$ Number of courses to be produced simultaneously. A program's offer can be structured by cohorts and likewise the production of the materials. If what must be produced exceeds the installed production capacity, and if time is a pressing matter, it is possible to subcontract. To decide if this course of action is possible, it is important to compare the internal production costs and times with those that are external, considering market prices, hiring pace and the ability to follow up and test what is produced or subcontracted.

$>$ Quality vs Costs. As for the course offering, costing is challenging, due to the pressures to ensure quality and reduce costs. Rumble (ibid., p. 82) states that usually, pressure is put on developers to achieve low teaching costs in the virtual component. Since digital technologies lead to increased interactions rather than reducing them, institutions are tempted to replace teachers (expert level) with assistants (lower expertise level), thus taking care of the cost but not necessarily ensuring the quality of the service. Universities with courses including large numbers of students at a time (thousands of students per course), such as the Open University of England, have employed the division of labor among those who develop the course, those who teach it and those who evaluate it to ensure quality. Unsurprisingly, tutoring and evaluation are done by personnel with service contracts. This model does not apply to institutions with a restricted number of students per course. Another solution to the quality vs. cost problem is to hire retired professionals with huge disciplinary experience, provided they are fluent in the use of technology and online accompaniment. If they are not, giving them proper training and advice for the fulfillment of their functions is an option.

$>$ Working charge per tutor. Another critical issue to consider in the course offering with virtual component is the working charge per tutor. According to Rumble (ibid., p. 81) in the US it is accepted that a group of 25 to 30 students demands 10 to $12 \mathrm{~h}$ per week from the tutor, meaning that in a full-time period, he could accompany 100 to 120 students. This means that the tutor knows about content and facilitation. Thus, it is convenient to train those who assume this role (Collison et al., 2002). Proposals for online facilitation have been very successful in this regard.

$>$ Replacement of academic staff functions to reduce costs. Within this perspective, it is possible to increase the teaching load of academics at the expense of other functions, such as research and extension, or to increase the graduate assistant staff and assign professionals with less experience to support experts.

$>$ Staff hiring policies. While the production of materials and course management should be done with faculty members as a factor of differentiation, other tasks can be done by people with service contracts (e.g. scripts, designs, tutoring, job qualification, etc.) $>$ Management costs of technology-supported programs are the least studied, but as proposed by Rumble (ibid., p.83) these are the ones with a greatest cost-effective potential and least cost documentation. The use of digital materials, the possibility of an automatic work flow of online academic and administrative processes, and the implementation of e-commerce practices with virtual or blended programs are opportunities that can be exploited. However, the costs of edu-commerce are not low and should be included within the development of virtual or blended learning universities rather than within the costs of their programs. Furthermore, Rumble sates that none of the studies reviewed adequately analyzes overhead costs. Here, two factors 
can be critical: equipment costs and management costs. Computer equipment and associated licenses are often considered, yet the costs of maintenance or replacement of networks and equipment are not. The same happens with project planning and evaluation costs, particularly when the virtual or blended programs are new to the institution.

\section{Strategy of change towards bLearning}

It is possible to take advantage of the opportunities offered by the bLearning modality when the appropriate conditions exist for innovation in an institution. In addition, if the organization accepts learning through a combination of face-to-face and virtual environments as a regular practice for, this is favorable. In this context, the careful conception and development of educational, operational and business models can help to reduce the uncertainty related to the understanding and development of this kind of innovations. However, for bLearning to go from being practice exclusive of innovative teachers to being adopted at an institutional level, it is essential to implement strategies for change.

\section{Current state of implementation and adoption of bLearning}

When institutions have not clearly defined and strategically adopted the bLearning modality, it is quite possible that this innovation arises only at course level (Graham et al., 2013). In all six cases of adoption of this modality in universities studied here, including public and private HEIs with a variety of missions and in different stages of bLearning adoption, the initiative began with innovative teachers who put it into practice. Although in some cases a good number of teachers came to adopt it by themselves, it was not until institutional policies, structures and support systems were defined that it was possible to advance institutionally (Graham et al., 2013).

Following the ideas on innovation dissemination stages proposed by Rogers (1983), Graham et al. (2013, pp. 27-29) found that institutions going through Stage 1 of a transition to bLearning (awarenes /exploration) know the organizational challenges this modality represents but have not yet adopted it. These institutions have found organizational challenges that could be solved with bLearning (e.g., providing access for more students, meeting the growing demand and/or optimizing the use of the physical infrastructure, greater learning flexibility, improving learning outcomes), but do not have a bLearning modality as an institutional strategy. Organizations in Stage 2 (early adoption / implementation) are often trying to create the appropriate conditions for the innovation to be successful such as: creating governance structures for the modality; adjusting the registration systems and the institutional catalog to clarify what the bLearning courses entail; initiating course development processes; starting pedagogical training; offering incentives to teachers to encourage them to rethink their courses. At this stage, it is common to find different efforts to standardize the desired results and corresponding learning assessments both in face-to-face and bLearning modalities. Institutions in Stage 3 (growth/mature implementation), have made this modality a part of their operation and are working 
on continuous improvement, taking special care of course and program evaluation and making decisions based on data.

\section{Transition between bLearning institutionalization stages}

A second study conducted by some of the authors mentioned above (Porter et al., 2014) followed eleven cases of bLearning adoption in public US universities. These institutions had different sizes and different levels of adoption depending on modality, mainly at the master's level, which allowed for the identification of patterns related to strategy, structure and support decisions during the transition. Table 6 shows the dimensions studied.

One of the study's initial findings (ibid., p. 28) is that, for the bLearning modality to be institutionalized, promoters must exist at different levels of the organization since this creates a shared vision and generates the necessary resources for the development of learning environments and materials, which leads to the adoption of bLearning by potential programs and their teachers. A second finding is that the existence of institutional guidelines on the modality is crucial to grant those who adopt it enough freedom to make educational decisions. This study also identified the need to develop the infrastructure to assist the migration from face-to-face courses to blended learning courses, ensuring that bLearning courses integrate the best pedagogical elements of both environments. The study indicates that it is key to provide technical and pedagogical support to both teachers and students in this modality. Furthermore, creating incentives for teachers, whether these involve financial compensation, workload reduction or promotion is recommended.

\section{Factors influencing adoption of bLearning by faculty members}

Above findings show that adoption of bLearning modality by institutions is intrinsically related to adoption of bLearning by faculty, the first one does not prosper without the second. Thus, it is important to understand what factors influence adoption of bLearning by faculty members.

A follow-up study by Porter and Graham (2016) trying to determine the degree to which institutional strategy, structure and support decisions facilitate or impede bLearning adoption among higher education faculty, "found that the

Table 6 Dimensions to consider for a bLearning implementation. Source:

(Porter et al., 2014, p. 36)

\begin{tabular}{|c|c|}
\hline Theme & Description \\
\hline Strategy & $\begin{array}{l}\text { Addresses issues relating to the overall design } \\
\text { of } B L \text {, such as definition of } B L \text {, and policies } \\
\text { surrounding it }\end{array}$ \\
\hline Structure & $\begin{array}{l}\text { Address issues relating to the technological, } \\
\text { pedagogical, and administrative framework } \\
\text { facilitating the BL environment, including } \\
\text { governance, models, scheduling structures, } \\
\text { and evaluation }\end{array}$ \\
\hline Support & $\begin{array}{l}\text { Address issues relating to the manner in } \\
\text { which an institution facilitates the implementation } \\
\text { and maintenance of its BL design, incorporating } \\
\text { technical support, pedagogical support, and faculty } \\
\text { incentives }\end{array}$ \\
\hline
\end{tabular}


availability of sufficient infrastructure, technological support, pedagogical support, evaluation data and an institution's purpose for adopting bLearning would most significantly influence faculty adoption" (Porter \& Graham, 2016, p. 748). These findings are very useful when HEI are setting up organizational infrastructures and resources (e.g., innovation centers to coach faculty members in the integration of digital technologies to their teaching) to foster adoption of bLearning in courses and programs.

By the same time Brown tried to establish what factors shape faculty member's adoption and use of bLearning in teaching, via review of empirical literature, and identified that six factors cut across studies (Brown, 2016, p. 1): faculty member's interactions with technology, academic workload, institutional environment, interactions with students, the instructor's attitudes and beliefs about teaching, and opportunities for professional development. Institutional assessment of these variables in HEI will allow to define strategies that help creating appropriate conditions for faculty adoption of bLearning in their teaching.

\section{Conclusions}

The purpose of this study was to support decision-making processes in HEIs that wish to use bLearning as a complement to other learning ecologies. Strategic thinking was used to frame institutional decision making about bLearning programs, and eleven sets of questions were proposed to guide tactical decision-making from the pedagogical, operational, and business perspectives. Literature review findings and lessons learned from good practices in eLearning and/or bLearning in six HEI offer some responses to those eleven sets of questions; to take full advantage of the opportunities that bLearning offers HEI decision-makers should answer guiding questions in the appropriate institutional context. Some conclusions from the study are:

$>$ Making well-informed, strategic decisions provide focus for the best course of action concerning the integration of bLearning modality as a complement to other learning ecologies. These decisions should build on the institution's identity and strengths, its potential allies, and the curricular, pedagogical and technological

opportunities. A shared vision between institutional academic decision-makers should lead the blended-learning innovation effort.

$\triangleright$ Sustainable and expandable bLearning initiatives in HEI, require institutional commitment with this way of teaching. It is vital to be clear about the role that blended modality can play as a differentiating educational factor, as an element that adds value to the learning process, or as an element that ensures an enduring, competitive advantage for the organization; these definitions gain commitment by the part of the HEI authorities.

$>$ Pilot testing this way of teaching and learning at the course level helps gain institutional knowledge and commitment; if this is not possible, critical success factors established from benchmarking studies such as (Galvis \& Pedraza, 2013) become very important to consult. Proof of concept for bLearning is particularly needed when bLearning programs are to be offered 
using multidimensional blends that seek to transform educational practices and/or expand academic services to new or larger and/or disperse audiences.

$>$ bLearning requires creating appropriate ecologies for faculty to (re)design and offer courses that get the best from face-to-face and virtual learning environments, initiatives that transform educational practices with support of technology. Teacher's time as course authors, course directors, learning facilitators or course evaluators should be considered, with the corresponding costs. Pedagogical and technological support for course and/or program creation, for curricular materials development with quality control, should be available. Financial resources to design and implement good quality initiatives should be ensured as a medium-term investment. Alignment of the educational value-chain and the corresponding administrative and technological support-chain processes for bLearning is a must.

$>$ Student-centered teaching using flexible learning environments usually implies deep changes both in faculty and in learners, as well as in academic administration practices. This cultural change requires taking into consideration the learning curve in shifting to a hybrid educational model. Depending on its level of maturity for bLearning, HEIs may require a transformation of their educational, operational, and/or business models.

$>$ An educational model is related to each set of elements that make it possible for beneficiaries of a bLearning program to participate in it, and to learn and become certified if applicable. Its components are the program's backbone and include the: (1) characterization of the blended learning environments, modes of interaction, and applicable resources; (2) examination of options to reach knowledge; (3) decisions about knowledge organization. These elements do not follow a pre-established order and there is much interaction between them, so adjustments in one component can modify another.

$>$ An operational teaching model refers to the set of elements that make it possible to implement the educational model. It includes decision-making processes related to the program and its courses, organizational structure to articulate processes, strategies to produce materials, student management throughout the course creation value chain, ICT management for the program, marketing and communication, management of tutorials and accompaniment, evaluation of effects, and impact and follow-up with graduates.

$>$ The business model for a program in bLearning modality includes aspects that must be considered to make it a viable and sustainable offer. Building on Rumble's (2001) proposals on pricing of online programs, this study suggests that the business models for bLearning programs should take two elements into account: 1) variables that can be controlled and that have an influence on costs; 2) cost factors associated with the development of materials, the courses offerings and program management.

$>$ The careful conception and development of educational, operational and business models can help to reduce the uncertainty related to the understanding and development of bLearning initiatives. However, for this modality to go from being practice exclusive of innovative teachers to being adopted at an institutional level, it is essential to implement strategies for 
change towards bLearning. This includes finding out the level of maturity towards the institutional use of the modality, as a framework to build bridges for the transition between institutionalization stages, as well as for the adoption of blended learning by faculty. The first one does not prosper without the second.

$>$ Decisions concerning the educational, operational, and business models are interrelated and frame the design of programs and courses in bLearning modality. They serve to align technologies, organizational structures, and change strategy with the desired bLearning vision.

\section{Endnotes}

${ }^{1}$ According to Wikipedia, Teleology is the branch of metaphysics that refers to the study of the ends or purposes of a certain object or being.

${ }^{2}$ Definition taken from http://www.dictionary.com/browse/tactic

${ }^{3}$ Conventional pedagogies are centered on the teacher and the transmission of knowledge, while active pedagogies, centered on the students and their groups, seek to reach knowledge from the action over objects of study and interaction amongst learners.

${ }^{4}$ ECTS-European Credit Transfer and Accumulation System-credits express the volume of learning based on the defined learning outcomes and their associates workload. One credit per academic term corresponds to 25 to $30 \mathrm{~h}$ of work (European Commission, 2015, p. 10), to be distributed along the number of weeks per academic term.

${ }^{5}$ For more information about inverted learning, see ITESM (2014).

${ }^{6} \mathrm{MERLOT}$ is a curated collection, contains open access resources for online teaching and learning, available at https://www.merlot.org/merlot/index.htm

${ }^{7} \mathrm{OCW}$ is a collection of complete courses, produced at MIT and released for open access, available at http://ocw.mit.edu/index.htm

${ }^{8} \mathrm{TEMOA}$ is a curated and open access educational resource portal managed by ITESM and available at http://www.temoa.info/es

${ }^{9} \mathrm{XPLORA}$ is the European portal for science education, open access and available at http://www.xplora.org/ww/en/pub/xplora/index.htm

${ }^{10} \mathrm{CC}$ is the website of Creative Commons https://creativecommons.org/, an organization that conceptualizes, proposes procedures and shares tools to manage digital goods of common interest (commons).

\section{Appendix 1}

\section{Definitions of ELearning Courses and Programs, Version 2.0 April 4, 2015}

"In developing the definitions below, we have tried to incorporate existing definitions developed by others and have incorporated comments from colleagues who have reviewed earlier drafts. We do not present these as the ultimate definitions, but as a step toward more commonly held standards as our field continues to evolve. Additions and revisions will be published periodically, as needed." (Mayadas et al., 2015) (Table 7) 
Table 7 Updated definitions of eLearning Courses and Programs, Version 2.0

\begin{tabular}{|c|c|c|}
\hline Level & Category & Characterization \\
\hline \multirow[t]{7}{*}{ Course-level } & 1. Classroom Course & $\begin{array}{l}\text { Course activity is organized around scheduled } \\
\text { class meetings }\end{array}$ \\
\hline & 2. Synchronous Distributed Course & $\begin{array}{l}\text { Web-based technologies are used to extend } \\
\text { classroom lectures and other activities to } \\
\text { students at remote sites in real time }\end{array}$ \\
\hline & 3. Web-Enhanced Course & $\begin{array}{l}\text { Online course activity complements class } \\
\text { sessions without reducing the number of } \\
\text { required class meetings. }\end{array}$ \\
\hline & $\begin{array}{l}\text { 4. Blended (also called Hybrid) Classroom } \\
\text { Course }\end{array}$ & $\begin{array}{l}\text { Online activity is mixed with classroom } \\
\text { meetings, replacing a significant percentage, } \\
\text { but not all required face-to-face instructional } \\
\text { activities. }\end{array}$ \\
\hline & $\begin{array}{l}\text { 5. Blended (also called Hybrid) Online } \\
\text { Course }\end{array}$ & $\begin{array}{l}\text { Most course activity is done online, but there } \\
\text { are some required face-to-face instructional } \\
\text { activities, such as lectures, discussions, labs, } \\
\text { or other in-person learning activities. }\end{array}$ \\
\hline & 6. Online Course & $\begin{array}{l}\text { All course activity is done online; there are } \\
\text { no required face-to-face sessions within the } \\
\text { course and no requirements for on-campus } \\
\text { activity }\end{array}$ \\
\hline & 7. Flexible Mode Course & $\begin{array}{l}\text { Offers multiple delivery modes so that students } \\
\text { can choose which delivery mode(s) to use for } \\
\text { instructional and other learning purposes. }\end{array}$ \\
\hline \multirow[t]{4}{*}{$\begin{array}{l}\text { Program- } \\
\text { level }\end{array}$} & 1. Classroom Program & $\begin{array}{l}\text { The program may include a mix of traditional, } \\
\text { web-enhanced, or hybrid courses, but all courses } \\
\text { require some face-to-face lecture sessions }\end{array}$ \\
\hline & 2. Multi-Format Program & $\begin{array}{l}\text { A program mixes classroom courses with other } \\
\text { formats that may use a variety of different delivery } \\
\text { modes, web-enhanced, blended, fully online courses, } \\
\text { synchronous distributed courses, etc., without a } \\
\text { specific access goal. }\end{array}$ \\
\hline & 3. Blended Program & $\begin{array}{l}\text { A significant percentage, but not all of the credits } \\
\text { required for program completion are offered fully } \\
\text { online }\end{array}$ \\
\hline & 4. Online Program & $\begin{array}{l}\text { All credits required to complete the program are } \\
\text { offered as fully online courses. }\end{array}$ \\
\hline
\end{tabular}

Source: (Mayadas et al., 2015)

\section{Appendix 2}

Interview guide for benchmarking on eLearning and bLearning in higher education

This document gathers the interview guidelines which were followed to update a benchmarking study conducted by the author in 2012 and reported later on (Galvis \& Pedraza, 2013). It was used to approach key informers from six HEI whose trajectory in eLearning and/or bLearning (from now on e-bLearning) is notorious. Informants were contacted by the interviewer and, upon acceptance, the interview-guidelines were sent along with a summary which tackled crucial aspects about their particular e-bLearning case. Over the course of the 3 years following this benchmarking process, it was truly significant to validate the available data and to understand the evolution of each of the cases.

\section{Instructions}

Feel free to focus your responses on those aspects that you consider to be the most relevant to describe your institutional experience in e-bLearning and/or to clarify 
information that we have collected about your e-bLearning case. If there are URLs or documents that will help us to understand your opinions about the issues addressed in the interview, please let us know by writing to a.galvis73@uniandes.edu.co

\section{Interview guidelines}

1. Beneficiaries. What are the target populations in the e-bLearning programs in your institution? What educational needs are privileged using this modality? To what extent is the educational $e$ - bLearning offer considered inclusive?

2. Educational model (s) in e-bLearning. What are the characteristics of the $e$ bLearning educational model in the institution? Which conceptual constructs (philosophical, pedagogical, technological) and operative constructs (educational technology, administrative-financial, educational research, instructional design, teaching) does it take into account?

3. Transformations of the educational model. Have there been transformations of this educational model over time? Which aspects have been predominant in each version of the model? What kind of difficulties or challenges have been faced in the implementation of this model? To what extent is the original or transformed educational model innovative in its conceptions, practices or tools?

4. Organizationally speaking. Where do initiatives to offer e-bLearning programs come from in your institution? What is the interaction between the virtual component and the face-to-face educational component of the University like (if both modalities exist)? If there is a support center for innovation with technologies, where does it report to? How is it organized? What is its reason for being? What products and services are offered?

5. Financially speaking. Which aspects are considered to determine the costs of an ebLearning program? What is the estimated time frame (or cohorts) to recover the investment on the design, development and offering of programs in this modality? If the financial parameters have not been determined yet, what has been the regular procedure followed in your institution to offer this type of program?

6. Management of e-bLearning (operating model). What (higher) instances of decision making regulate or support the offer of programs in the e-bLearning modalities? What institutional and external actors intervene in the processes of the value and support chains? What strategies are used to make the operation of programs in these modalities cost effective?

7. Human capital management for e-bLearning. What are the procedures for hiring teachers who participate in e-bLearning courses or programs? What is the regular teaching load of teacher-authors and tutors?

8. Human capital development for e-bLearning. What competencies are sought after or promoted by the course directors and their facilitators? How are teachers trained and monitored on the desired competencies? Which strategies are implemented for the professional development of teachers participating in e-bLearning?

9. Student support services. From the perspective of the operating model, how are services such as: introduction to the educational modality, tutoring, counseling, digital library, student welfare, support for content management and 
self-management of work groups carried out? Who is responsible for what? How are these groups organized if it's the case?

10. Communication with and between students. Considering synchronous and asynchronous communication, is there a pattern, or guideline, to communicate with students, or does each tutor and counselor proceed in his/her way? If social networks are used institutionally to support interaction with and among students, what technologies are used and for what purposes? If there has been an assessment of the effectiveness of communication with students, what lessons have been learned?

11. Technology to support learning in virtual environments. What synchronous and asynchronous technologies (e.g., virtual classroom, web 2.0 applications, collaborative and immersive environments, self-publishing and publication of content, labeling of information, use of RSS for syndication in courses, integrated agendas to mail, 2D and 3D virtual worlds) are available for use with institutional support? How do those in charge of the conceptual and the operating models make decisions on how the technology and virtual environments used in each course should interact? Culturally, what fears, or expectations, have been detected in relation to technologies to support student services?

12. Internal and external multimedia content (in multiple formats, open access or proprietary, Mobile learning) What content is produced? What repositories are used? What are the trends in virtual programs?

13. Copyright issues. How are copyrights handled? How and who watches over copyright?

14. Academic and operational knowledge management: To what extent does knowledge management in virtual programs draw on what teachers and/or students generate? To what extent is knowledge management only an individual activity? What strategies are used to make organizational learning in virtual programs and courses possible?

15. Motivation / participation (engagement) of teachers and students. What strategies are used to develop a sense of belonging and commitment of students and teachers in the modality? What are the rates of graduation and retention and what is done to overcome them? What is the pattern of action to prevent dropping out and to overcome situational problems (spatio-temporal and others) of students?

16. Evaluation of learning. What is the focus of the assessment effort in courses in $e$ bLearning modalities: concepts, skills, competences? What type of assessment instruments are predominant: exams, quizzes, projects, problems, cases? How widespread is the use of forum, blogs, wikis, e-portfolios, and rubrics for assessment?

17. Quality assessment, evaluation of effects and impact of e-bLearning courses. Which research subjects privilege the assessment that seeks improvement throughout the process? How is the assessment carried out at the end of the process, if that's the case? Which actors are taken into account and for what purpose? If course evaluation has not been done, what are your forecasts?

18. Key Success Factors (KSF) in e-bLearning. What needs to be done well to be successful in this initiative? What should not be done to avoid failing in e-bLearning courses and programs? Which KSF are considered strategic (out of those included in the two lists of KSF) and which are operational (out of those included in one of the two lists of KSF)?

Interview guide created by Galvis, September 2015. 


\section{Abbreviations}

ALS: Arizona learning systems; bLearning: Blended learning; CC: Concord consortium; CMS: Content management system; Colciencias: Colombian national science foundation; Conecta-TE: Center for innovation in technology and education; eLearning: Electronic learning; HEl: Higher education institution; ICT: Information and communication technologies; KM: Knowledge management; LMS: Learning management system; MINEDUCACION: Colombian National Ministry of Education; MININTERIOR: Colombian National Ministry of the Interior; OA: Open access; OIT: Organization, individual, and technology; OLC: Online learning consortium; OS: Open source; UNIANDES: University of Los Andes, Bogota, Colombia; UOC: Universitat Oberta from Catalunya, Barcelona, Spain; VLO: Virtual learning objects

\section{Acknowledgments}

This document received valuable contributions from the UNIANDES' LIDIE research group, as well as from members of other university's groups who have been engaged in this elearning and/or bLearning. Luz Adriana Osorio, Maria Fernanda Aldana, Olga Mariño, Gary Cifuentes, Gloria Cortés, from Uniandes; Marlyn Aaron and Patricia Choles, from the Uniguajira's Motivar research group; Josep M. Duart, from the UOC, and many other researchers have made invaluable contributions. To all of them, thank you very much.

\section{Funding}

This document was prepared as part of the $\mathrm{R}+\mathrm{D}$ project approved to Uniandes by Colciencias for the Development and validation of a methodology for the sustainable generation of educational programs in bLearning modality. This project was granted within the framework of the call 691-2014 of Colciencias for tax deductions of $\mathrm{R}+\mathrm{D}$ for projects of 2015, with contributions from the Gabriel Vegalara Foundation.

\section{Availability of data and materials}

Case studies data and material are available in supporting text files from the author, manuscripts in Spanish.

\section{Authors' contributions}

ÁHG is the main and only author of this document. The author read and approved the final manuscript.

\section{Authors' information}

Álvaro Hernán Galvis is a Full Professor at the University of los Andes. He is a Systems and Computing Engineer and holds a Doctorate in Education. He is part of the UNIANDES-LIDIE research group of Conecta-TE, the Center for Innovation in Technology and Education of the School of Education of the same institution.

\section{Competing interests}

The author declares that he has no competing interests.

\section{Publisher's Note}

Springer Nature remains neutral with regard to jurisdictional claims in published maps and institutional affiliations.

Received: 7 February 2018 Accepted: 26 April 2018

Published online: 01 June 2018

\section{References}

Allen, J. E., Seaman, J., \& Garret, R. (2007). Blending in - the extent and promise of blended education in the United States. Retrieved from Online Learning Consortium: https://secure.onlinelearningconsortium.org/publications/ survey/blended06.

ALS (1998). Preliminary cost methodology for distance learning. Phoenix: Arizona Learning Systems and the State Board of Directors for Community Colleges of Arizona.

Bart, M. (2008). Distance education - measuring the benefits and costs. Retrieved from Faculty Focus - Higher Ed teaching strategies from Magna Publications: http://www.facultyfocus.com/articles/distance-learning/distanceeducation-measuring-the-benefits-and-costs/. Accessed 1 Mar 2018.

Bates, A. W. (2015). Teaching in a digital age. Guidelines for designing teaching and learning for a digital age. Tony Bates Associates Ltd. Retrieved from https://opentextbc.ca/teachinginadigitalage/. Accessed 1 Mar 2018.

Bersin, J. (2004). The blended learning book: Best practices, proven methodologies, and lessons learned. San Francico: John Wiley \& Sons.

Brookes, M., \& Becket, N. (2007). Quality management in higher education: A review of international issues and practices. International Journal for Quality and Standards, 1(1), 85-121.

Brown, M. G. (2016). Blended instructional practice: A review of empirical literature on instructors' adoption and use of online tools in face-to-face. The Internet and Higher Education, 31, 1-10.

Burkei, N. (2014). Benchmarking your university: Why and how? European Association for. International Education Retrieved from https://www.eaie.org/blog/benchmarking-your-university/. Accessed 1 Mar 2018.

Churchman, C. (1968). The systems approach. New York: Delacorte Press.

Collison, G., Elbaum, B., Haavind, S., \& Tinker, R. F. (2002). Facilitating online learning: Effective strategies for online facilitators. Madison: Atwood Publishing.

Erickson, H. L. (2007). Concept-based curriculum and instruction for the thinking classroom. Thousand Oaks: Sage Publications Ltd.

European Commission. (2015). ECTS Users' Guide 2015. Retrieved from European Commission - Education and Training: https://ec.europa.eu/education/sites/education/files/ects-users-guide_en.pdf. Accessed 1 Mar 2018.

Forté, E., \& Wentland, M. (1998). The ARIADNE project: Knowledge pools for computer-based and telematics supported classical, open and distance education, AAUC Ariadne academic users group conference (pp. 1-23). Lucerna: AAUC. 
Galvis, Á. H. (1982). Universidades a distancia en latinoamérica: un análisis comparativo en lo metodológico. San José: EUNED.

Galvis, Á. H. (2017a). AHA, más allá de APA con AVA, donde las mezclas deben ser multidimensionales. In P. Ávila Muñoz, \& C. Rama Vitale (Eds.), Internet y educación: amores y desamores, (1st ed., pp. 179-200). México: INFOTEC Centro de Investigación e Innovación en Tecnologías Retrieved from https:/www.infotec.mx/es_mx/infotec/libros_electronicos.

Galvis, Á. H. (2017b). Documentación de casos institucionales de buenas prácticas en bLearning y/o elearning en educación superior. Bogotá: UNIANDES - ConectaTE: Anexo 4 de Informe final a Colciencias proyecto "Desarrollo y validación de una metodología para la generación sostenible de programas educativos en la modalidad Blended Learning" (manuscrito).

Galvis, Á. H. (2018). Direccionamiento estratégico de la modalidad híbrida en educación superior: Conceptos, métodos y casos para apoyar toma de decisiones. Bogotá: Ediciones Uniandes in press.

Galvis, Á. H., Mclntyre, C., \& Hsi, S. (2006). Framework for the design and delivery of effective global blended learning experiences - a report prepared for the World Bank Group. Concord: The Concord Consortium (manuscript).

Galvis, Á. H., \& Osorio, L. A. (2017). Formación avanzada en modalidad híbrida de enseñanza: Una década de experiencias y lecciones aprendidas en Universidad de los Andes, Teledu 2017 XXIII Congreso Internacional sobre Educación Bimodal (pp. 1-11). Cartagena: CIMTED Corporación Retrieved from http://teleducom.com/.

Galvis, Á. H., \& Pedraza, L. C. (2012). Rediseño de cursos para la comprensión de grandes ideas e integración de tecnologías para el aprendizaje. Revista de Tecnología de Información y Comunicación en Educación, 6(2), 11-45 Retrieved from http://servicio.bc.uc.edu.ve/educacion/eduweb/vol6n2/art1.pdf.

Galvis, Á. H., \& Pedraza, L. C. (2013). Desafíos del bLearning y del eLearning en educación superior. In N. Arboleda Toro, \& C. Rama Vitale (Eds.), La educación superior a distancia y virtual en Colombia: nuevas realidades, (pp. 113-154). Bogotá: Virtual Educa y ACESAD.

Ginns, P., \& Ellis, R. (2007). Quality in blended learning: Exploring the relationships between on-line and face-to-face teaching and learning. The Internet and Higher Education, 10(1), 53-64.

Graham, C. R. (2006). Blended learning systems: Definitions, current trends, and future directions. In The handbook of blended learning: Global perspectives, local designs, (pp. 3-21). San Francisco: Jossey-Bass / Pfeiffer.

Graham, C. R., Woodfield, W., \& Harrison, J. (2013). A framework for institutional adoption and implementation of blended learning in higher education. Internet and Higher Education. https://doi.org/10.1016/j.iheduc.2012.09.003.

Green, D. (1994). What is quality in higher education? Concepts, policy and practice. In D. Green (Ed.), What is quality in higher education? (pp. 3-20). Buckingham: Society for Research into Higher Education \& Open University Press.

Henderson, J., \& Venkatraman, N. (1994). Strategic alignment: A model for organizational transformation via information technology. In T. Allen, \& M. Scott Morton (Eds.), Information technology and the Coorporation of the 1990's research studies, (pp. 202-220). New York: Oxford University Press.

Jannetti, A. J. (2012). A representation: Incorporating a needs assessment and gap analysis into the educational design. Janetti Inc. Pitman: Author.

Kirkwood, A., \& Price, L. (2014). Technology-enhanced learning and teaching in higher education: What is ' enhanced'and how do we know? A critical literature review. Learning, Media and Technology, 39(1), 6-39.

Lai, M., Lam, K. M., \& Lim, C. P. (2016). Design principles for the blend in blended learning: A collective case study. Teaching in Higher Education, 21(6), 716-729. https://doi.org/10.1080/13562517.2016.1183611.

Lee, O., \& Im, Y. (2014). Innovation of higher education in the globalized era - emerging trends report 2013-2014. In R. H. Kinshuk, \& J. K. Price (Eds.), ICT in education in global context, (pp. 221-247). Berlin: Springer. https://doi.org/10. 1007/978-3-662-43927-2

Liu, X., \& Chen, X. (2017). Disruptive technology enhanced learning: The use and misuse of digital technologies in higher education, Innovations in education and teaching international (pp. 1-2). https://doi.org/10.1080/14703297.2018. 1405550

Mason, R., \& Rennie, F. (2006). Elearning - the key concepts. New York: Routledge - Taylor \& Francis Group.

Mayadas, F., Miller, G., \& Sener, J. 2015. Definitions of E-learning courses and programs version 2.0 April 4, 2015. Retrieved from Online Learning Consortium - OLC Insights: OLC's blog: https://onlinelearningconsortium.org/ updated-e-learning-definitions-2/

Means, B., Toyama, Y., Murphy, R., Bakia, M., \& Jones, K. (2010). Evaluation of evidence-based practices in online learning: A meta-analysis and review of online learning studies. Washington: US Department of Education, Office of Planning, Evaluation, and Policy Development.

MINEDUCACION. (2003). Registro calificado para programas de educación superior. Retrieved from Ministerio de Educación Nacional República de Colombia: http://www.mineducacion.gov.co/1621/article-85583.html.

MINEDUCACION (2012). Orientaciones para el diseño, producción e implementación de cursos virtuales. Bogotá: Autor Retrieved from http://virtualpostgrados.unisabana.edu.co/pluginfile.php/426529/mod_resource/content/1/ Orientaciones_E-Learning.pdf.

MININTERIOR. (2016). DNDA ¡Promovemos la creación! Retrieved from Dirección Nacional de Derecho de Autor Unidad Administrativa Especial Ministerio del Interior: http://derechodeautor.gov.co/.

Mintzberg, H. (1994). The fall and rise of strategic planning, (pp. 107-113). Harvard Business Review Retrieved from https://hbr.org/1994/01/the-fall-and-rise-of-strategic-planning. Accessed 1 Mar 2018.

Mitchell, I., Keast, S., Panizzon, D., \& Mitchell, J. (2017). Using 'big ideas' to enhance teaching and student learning Teachers and Teaching - Theory and practice. https://doi.org/10.1080/13540602.2016.1218328.

Mykhnenko, V. (2016). Cui bono? On the relative merits of technology-enhanced learning and teaching in higher education. Journal of Geography in Higher Education, 40(4), 585-607.

Ohmae, K. (1990). La mente del estratega: el triunfo de los japoneses en el mundo de los negocios. Buenos Aires: McGrawHill.

Osorio Gómez, L. A. (2009). Interacción en ambientes híbridos de aprendizaje - Metáfora del continuum, Open University of Catalunya, information and knowledge society doctoral dissertation (). Barcelona: manuscript. http://www.red-redial. net/referencia-bibliografica-58462.html.

Osorio Gómez, L. A. (2011). Interacción en ambientes híbridos de aprendizaje: Metáfora del contínuum. Barcelona: Editorial UOC

Osorio Gómez, L. A., \& Duart, J. M. (2012). A hybrid approach to university subject learning activities. British Journal of Educational Technology, 43(2), 259-271. https://doi.org/10.1111/j.1467-8535.2011.01175.x. 
Pavla, S., Hana, V., \& Jan, V. (2015). Blended learning: Promising strategic alternative in higher education. Procedia Social and Behavioral Sciences, 171, 1245-1254.

Penrod, J. I., \& Dolence, M. G. (1992). Reengineering; a process for transforming higher education. CAUSE - the Association for the Management of information Technology in Higher Education. CAUSE. Retrieved from https:// www.educause.edu/ir/library/pdf/PUB3009.pdf. Accessed 1 Mar 2018.

Porter, M. E. (1982). Estrategia competitiva - técnicas para análisis de los sectores industriales y de la competencia. México: CECSA

Porter, W., Graham, C., Spring, K. A., \& Welch, K. (2014). Blended learning in higher education: Institutional adoption and implementation. Computers \& Education, 75, 185-195. https://doi.org/10.1016/j.compedu.2014.02.011.

Porter, W. W., \& Graham, C. (2016). Institutional drivers and barriers to faculty adoption of blended learning in higher education. British Journal of Educational Technology, 47(4), 748-762. https://doi.org/10.1111/bjet.12269.

Rahman, N. A., Hussein, N., \& Aluwi, A. H. (2015). Satisfaction on blended learning in a public higher education institution: What factors matter? Procedia - social and behavioral sciences (pp. 768-775).

Rogers, E. M. (1983). Diffusion of innovations. New York: Free Press.

Rosenberg, M. (2006). Beyond e-learning: Approaches and technologies to enhance organizational knowledge, learning, and performance. San Francisco: Pfeiffer.

Rossett, A., \& Frasee, R. V. (2006). Blended learning opportunities. Retrieved from ResearchGate: http://www. researchgate.net/publication/228669485_Blended_Learning_Opportunities. Accessed 1 Mar 2018.

Rovai, A. P. (2002). Building sense of community at a distance. IRRODL international review of research in open and distributed learning, 3(1). Retrieved from http://www.irrodl.org/index.php/irrodl/article/view/79/152. Accessed 1 Mar 2018.

Rumble, G. (1999). Cost analysis of distance learning. Performance Improvement Quarterly, 12(2), 122-137. https://doi.org/10.1111/j.1937-8327.1999.tb00133.x.

Rumble, G. (2001). The costs and costing of networked learning. Journal of Asynchronous Learning Network, 5(2), 75-96 Retrieved from Researchgate: https://www.researchgate.net/publication/228481358_The_Costs_and_Costing_of_ Networked_Learning.

Sáez Vacas, F. (1997). La innovación tecnológica, un instrumento preestratégico: un modelo sociotécnico. In Á. H. Galvis, \& Á. Espinosa (Eds.), Estrategia, competitividad e informática, (pp. 43-62). Bogotá: Ediciones Uniandes.

Singh, H. (2003). Building effective blended learning programs. Educational Technology, 43(6), 51-43.

Solar, M., Sabattin, J., \& Parada, V. (2013). A maturity model for assessing the use of ICT in school education. Educational Technology \& Society, 16(1), 206-218 Retrieved from https://pdfs.semanticscholar.org/7b3b/ 48fc191f0f2478b007418d02414123017568.pdf.

Sparkes, J. (1984). Pedagogic differences in course design. In A. W. Bates (Ed.), The role of Technology in Distance Education. London: Croom Helm.

Suffolk County Community College. (2004). Needs assessment. Retrieved from Title III - Strenghtening institutional programs: http://depthome.sunysuffolk.edu/Title3/id/Steps/needs_assessment.htm. Accessed 1 Mar 2018.

Svendsen, A., \& Laberge, M. (2007). Mapping a stakeholder network. Retrieved from Masterfulfacilitation.com: http:// masterfulfacilitation.com/articles/mapping.pdf. Accessed 1 Mar 2018.

Tanweer, M., \& Qadri, M. M. (2016). Quality assurance in higher education: A framework for distance education. JDER Journal of Distance Education \& Research, 1(1), 6-24.

Tinker, R. F., Haavind, S., Galvis, A. H., Rose, R., Mclntyre, C., \& Smith, A. (2002). El modelo de Concord para aprendizaje a distancia. Retrieved from Metacursos SAS: https://goo.gl/sLvkwC. Accessed 1 Mar 2018.

UOC (2009). El modelo educativo de la UOC - evolución y perspectivas. Barcelona: Universitat Oberta de Catalunya.

Wiggins, G., \& McTighe, J. (2001). Understanding by design. Upper Saddle River: Merril Prentice Hall.

\section{Submit your manuscript to a SpringerOpen ${ }^{\oplus}$ journal and benefit from:}

- Convenient online submission

- Rigorous peer review

Open access: articles freely available online

- High visibility within the field

- Retaining the copyright to your article

Submit your next manuscript at $\gg$ springeropen.com 